\title{
Factors regulating the production of different inducers in Pseudomonas aeruginosa with reference to larval metamorphosis in Balanus amphitrite
}

\author{
L. Khandeparker, A. C. Anil* ${ }^{*}$ S. Raghukumar
}

Marine Corrosion \& Materials Research Division, National Institute of Oceanography, Dona Paula, Goa 403 004, India

\begin{abstract}
Gregarious settlement in barnacles has been related to the settlement-inducing compounds from adult conspecifics, bacteria in the biofilms, and their interaction. Elucidation of larval settlement cues from these sources is limited. The effectiveness of larval settlement cues under different environmental conditions (salinity, temperature) needs evaluation. Pseudomonas aeruginosa, a bacterium isolated from the shell surface of Balanus amphitrite Darwin, was used as a candidate. The influence of bacterial film, culture supernatant and its molecular-weight fractions, and bacterial extract was investigated along with the conspecific adult extract (AE). The influence of culture supernatants and exopolysaccharides obtained from the bacterium cultivated in different nutrient media, effectiveness of leachants and adsorbed (surface-bound) compounds on the metamorphosis of cyprids of $B$. amphitrite was also assessed. The influence of $P$. aeruginosa on cyprid metamorphosis varied with salinity and temperature. The differences were not significant as the film and the cyprids aged. When the bacterial film was examined in the presence of an active substance (agonist) such as AE, metamorphosis was facilitated, suggesting the role of competitive antagonism in cue perception. The higher molecular-weight fraction of the bacterial-culture supernatant was inductive at higher salinity. Conversely, the lower molecular-weight fraction of the culture supernatant showed maximum inhibition when the adsorbed (surface-bound) compounds were assessed along with the leachants. Bacterial extract showed the presence of ketonic compounds, and its influence differed with salinity. The inhibitory effect of the extract was nullified in the presence of AE. When the extract was examined in the presence of leachants, a 2-fold increase in the metamorphosis rates was evident where only surface-bound components were inhibitory. Fourier transformed infrared spectroscopy analysis revealed that bacteria grown in different nutrient media yielded culture supernatants with different chemical composition, thus altering their ability to induce metamorphosis of cyprids. Maximum inducement was provoked by the culture supernatant obtained from semi-solid culture, and this positive effect was protein concentration dependent. The exopolysaccharides obtained from bacteria grown in basal salt solution facilitated metamorphosis similar to that of the bacterial film and AE. The response of the cyprids to bacteria and its products seems to be regulated by both contact chemoreception and olfaction, depending on the properties of the settlement-inducing compounds. The need to characterize and distinguish the receptors, which act via different signaling systems on a particular settlement cue, may be a step ahead to resolve the complexities of invertebrate larval recruitment.
\end{abstract}

KEY WORDS: Pseudomonas aeruginosa ' Balanus amphitrite ' Cyprid · Metamorphosis · Exopolysaccharides · Culture supernatant

Resale or republication not permitted without written consent of the publisher

\section{INTRODUCTION}

Balanus amphitrite Darwin is a dominant fouling organism found all over the world. The larval develop-

${ }^{*}$ Corresponding author. E-mail: acanil@darya.nio.org ment of this organism includes 6 naupliar instars and a non-feeding presettling cyprid instar. B. amphitrite breeds throughout the year in Indian waters (Karande 1967, Anil 1986) and is euryhaline (Anil et al. 1995).

Cypris larvae test various areas before finally attaching to any substratum. A series of factors such as

() Inter-Research $2002 \cdot$ www.int-res.com 
surface type, water flow, light, temperature, larval age, competitors and the chances of success in reproduction (Crisp 1974) are important in the choice of a settlement site. In addition, the most important factors or determinants for settlement are the specific chemical cues or triggers associated with the substratum (Kirchman et al. 1982a, Morse 1984a,b, Maki \& Mitchell 1985, Szewzyk et al. 1991, Qian et al. 2000). Competent larvae metamorphose only after encountering certain environmental cues associated with habitat appropriate for the juvenile (Pechenik 1990, Pawlik 1992). Surface chemistry is also very important for larval settlement and plays a role in the distribution of adults (Strathmann et al. 1981). Several studies have shown that many marine invertebrate larvae settle and metamorphose in response to extracellularly produced components and other environmental stimuli; hence, the behavioral and morphogenetic responses may be triggered by different inducers (Rodriguez et al. 1993). Settlement and metamorphosis are shown to be controlled by larval sensory recognition, which transduces the external signals into signals within the organism (Pawlik 1992).

Field and laboratory studies have shown that barnacle cyprids prefer to metamorphose on or near conspecifics. The responsible settlement pheromone or positive cue has been recognized as arthropodin or settlement factor $(\mathrm{SF}+)$, a glycoprotein present in the adults (Knight-Jones 1953, Knight-Jones \& Crisp 1953, Crisp \& Meadows 1963). Balanus amphitrite cyprids like B. balanoides (Walker \& Yule 1984) have been shown to deposit footprints of temporary adhesive while exploring a substratum that stimulates the settlement of other cyprids, even in the absence of conspecific adults (Yule \& Walker 1985, Clare et al. 1994).

Besides adult conspecifics, bacterial films (BF) coating the benthic substrates have been suggested as sources of waterborne cues mediating settlement of oyster larvae (Bonar et al. 1986, Fitt et al. 1989, Tamburri et al. 1992). Barnacle cyprids like most other larvae prefer to settle on the substrata that possess a welldeveloped biofilm (Crisp 1984, Clare et al. 1992). The tenacity of temporary adhesion of cyprids to unfilmed substrata or BF does not always correlate with their final fixation (Maki et al. 1994). The studies related to interactions between cypris larvae and BF have generally found most bacterial species to inhibit attachment of Balanus amphitrite cyprids to polystyrene surfaces, although several bacterial species showed no effect (Maki et al. 1988, 1990, 1992, Avelin Mary et al. 1993, Neal \& Yule 1994a,b). The influence of BF and the culture supernatant (CS) containing extracellular materials on the settlement of $B$. improvisus Darwin cyprids has been shown to differ when examined in the field from that observed in the laboratory $\left(\mathrm{O}^{\prime}\right.$ Connor \&
Richardson 1996). Recently, thraustochytrid protists, which are found in marine microbial films, have been shown to induce the settlement of $B$. amphitrite (Raghukumar et al. 2000).

The effect generated by bacterial strains, whether stimulatory or inhibitory for larval settlement, is amplified with the age of the film (Maki et al. 1989, Holmström et al. 1992). The presence of a bacterial biofilm has been interpreted as a general signal that a surface is neither temporary nor toxic, and larvae may use more specific chemical signatures from biofilms or characteristic microbial assemblages to indicate preferred ecological conditions at a site (Unabia \& Hadfield 1999). The bacteria influence settlement by changing the nature of the substratum, either by altering the surface wettability or by exposing different surface molecular domains, for example in the form of exopolymers (Anil et al. 1997). Bacteria can also produce surface-bound and soluble chemical cues that either stimulate or inhibit larval settlement (Kirchman et al. 1982a, Maki et al. 1990, 1992) Szewzyk et al. 1991.

A wide variety of bacterial supernatants also appeared to influence the search behavior of the oyster Crassostrea gigas larvae via ammonia gas and other weak amine bases (Bonar et al. 1990). For a chemical cue to be effective against larvae it must be either present on the surface of the substratum or released into the surrounding water (waterborne cues), both of which have been documented in the literature (Crisp \& Meadows 1962, 1963, Morse et al. 1980, Hadfield \& Scheuer 1985, Jensen \& Morse 1990, Tamburri et al. 1992).

Adult conspecifics, the biofilms on their shell surfaces or the interaction of both have been debated for their source of origin of various settlement-inducing compounds that cause gregarious settlement in barnacles. Anil \& Khandeparker (1998) and Anil et al. (1997) reported that in Balanus amphitrite cyprids the degree of inducement of metamorphosis varied with various combinations of exopolymers of different bacterial strains with or without adult extract (AE).

We carried out 4 different experiments (Fig. 1) to study the influence of settlement-inducing compounds from Pseudomonas aeruginosa, a bacterium isolated from the shell surface of Balanus amphitrite, on the cyprid metamorphosis of $B$. amphitrite. In Expt 1 the influence of BF was assessed under different environmental conditions (salinity and temperature). The CS, its molecular-weight (MW) fractions and bacterial extract were subjected to cyprid metamorphosis assays. The influence of BF and its products was also assessed along with conspecific AE. In Expt 2 the effectiveness of leachants and surface-bound compounds was assessed. In Expt 3 the effect of CS produced by the bacteria 


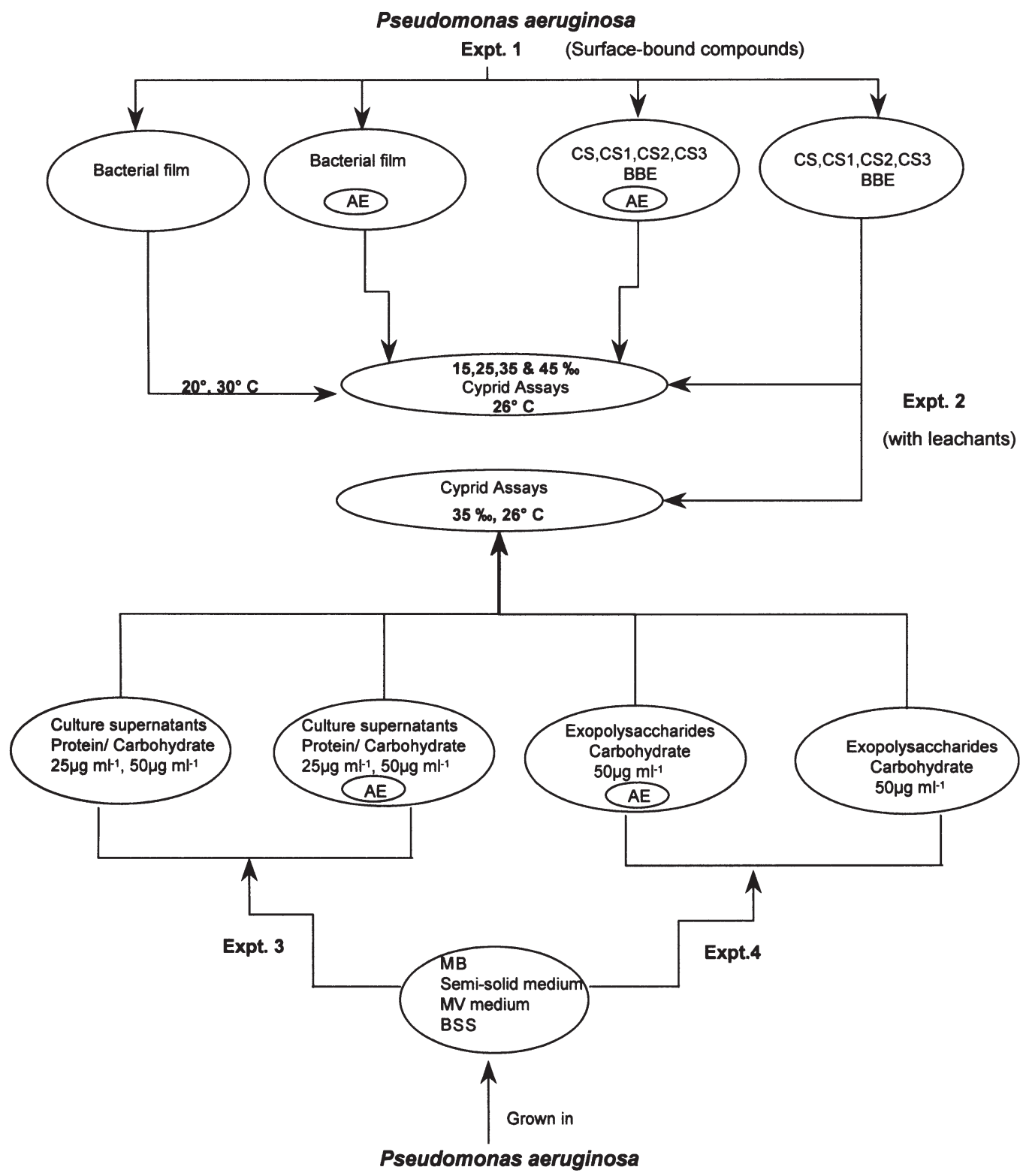

Fig. 1. Schematic representation of the experimental set-up. All the experiments included adult extract (AE) as the positive control and filtered seawater (FSW) as the negative control. BF: bacterial film; BBE: butanol-bacterial extract; CS: culture supernatant; CS1: MW < 10 000; CS2: MW = 10000 to 30 000; CS3: MW > 30 000; MV: modified Vishniac's medium; MB: marine broth; BSS: basal salt solution

grown in different nutrient media was evaluated along with the AE. In Expt 4 the effectiveness of bacterial exopolysaccharides (EPS) extracted using different nutrient media was investigated.

\section{MATERIALS AND METHODS}

Preparation of the AE. AE was prepared by following the method described earlier by Larman et al. (1982). Adults of Balanus amphitrite, collected from the intertidal area of Dona Paula $\left(15^{\circ} 27.5^{\prime} \mathrm{N}, 73^{\circ} 48^{\prime} \mathrm{E}\right)$, were brought to the laboratory and cleaned by brush- ing off the epibiotic growth on their shells using a nylon brush. The animals were then washed and $100 \mathrm{~g}$ wet wt of whole adults was crushed with a mortar and pestle using $100 \mathrm{ml}$ of deionized water (reverse osmosis [RO] pure). The supernatant of the crushed mixture was decanted, centrifuged at $12000 \times g$ for 5 min and thereafter boiled for $10 \mathrm{~min}$ in a boiling water bath. The extract was again centrifuged at $12000 \times g$ for $5 \mathrm{~min}$ and then frozen at $-20^{\circ} \mathrm{C}$ until further use. The protein content of the extract was estimated following the method of Lowry et al. (1951). Bovine serum albumin (BSA) was used as the standard. A protein concentration of $50 \mu \mathrm{g} \mathrm{ml}^{-1}$ of AE was used for all assays. 
Rearing of Balanus amphitrite larvae. The life cycle of $B$. amphitrite includes planktotrophic larval development consisting of 6 naupliar instars and a non-feeding cyprid instar. The first instar nauplii do not feed, and they molt into the second instar within a few hours. Instars II to VI are phytoplanktotrophic. Nauplii were mass reared in 21 glass beakers using filtered seawater (FSW) of 35\% salinity on a diet of Chaetoceros calcitrans, a unicellular diatom, at a cell concentration of $2 \times$ $10^{5}$ cells $\mathrm{ml}^{-1}$. The food organism was replenished every day while changing the water. After 5 to $6 \mathrm{~d}$ the cyprids obtained were siphoned out and stored at $5{ }^{\circ} \mathrm{C}$ prior to settlement assays. Cyprids ( $2 \mathrm{~d}$ old) were used for the assays. These methods have been described in detail by Rittschof et al. (1984).

Isolation of bacteria from shell surfaces of Balanus amphitrite. $B$. amphitrite were brought to the laboratory and rinsed with deionized water (RO pure) to remove dirt. The animals were then scraped with a nylon brush using Millipore-filtered autoclaved seawater under sterile conditions. The sample was further diluted and spread plated on Zobell Marine Agar 2216. The bacterial colonies thus isolated were maintained on Zobell Marine Agar 2216 slants. The purity of the culture was checked by streaking on Zobell Marine Agar 2216. Bacteria were identified following 'Bergy's manual of systematic bacteriology' (Krieg 1984). Pseudomonas aeruginosa was chosen for the present investigation. The results of the morphological and biochemical tests employed to identify the bacterium are given in Table 1.

Expt 1. BF: The influence of BF on the metamorphosis of cyprids of Balanus amphitrite was assessed at different salinities $(15,25,35$ and $45 \%$ ) and temperatures $\left(20,26\right.$ and $30^{\circ} \mathrm{C}$ ) and compared with AE (positive control) and FSW (negative control). The surfaces were covered with bacterial film following the methods previously described by Maki et al. (1988, 1990). The dishes with the bacterial treatment were fixed with formaldehyde (final concentration 1 to $2 \%, v / v$ ) and the attached bacteria were quantified by using acridine orange and epifluorescence microscopy. In this way the bacterial density was determined (Daley \& Hobbie 1975). The adsorption technique resulted in densities of $10^{6}$ to $10^{7}$ attached bacteria $\mathrm{cm}^{-2}$.

CS and its fractions: The bacterium was grown in basal salt solution (BSS), $\mathrm{pH} 7.5$, containing $\left(\mathrm{g} \mathrm{l}^{-1}\right) \mathrm{NaCl}$ 30.0, $\mathrm{KCl} 0.75, \mathrm{MgSO}_{4} \cdot 7 \mathrm{H}_{2} \mathrm{O} 7.0, \mathrm{NH}_{4} \mathrm{Cl} 1.0, \mathrm{~K}_{2} \mathrm{HPO}_{4}$ $0.7, \mathrm{KH}_{2} \mathrm{PO}_{4} 0.3$ and glucose 10.0 , and $1 \mathrm{ml}$ of trace metal solution (Bhosle 1981). A $2 \%(\mathrm{v} / \mathrm{v})$ inoculum of an $18 \mathrm{~h}$ old culture grown in the same medium was used. After $48 \mathrm{~h}$, when the culture reached stationary phase, cells were centrifuged at $20000 \times g$ for $15 \mathrm{~min}$ at $4^{\circ} \mathrm{C}$. The supernatant was filtered through a $0.22 \mu \mathrm{m}$ Millipore filter and the resultant filtrate was used as the CS in the assays. Subsequently, 3 subsamples were concentrated in a stirred ultrafiltration cell (Amicon) to one-tenth of the original volume using filters with a nominal MW cut-off of 3000, 10000 and 30000 sequentially. The fractions between 3000-10000 MW, 10000-30000 MW, and MW> 30000 have been abbreviated to CS1, CS2 and CS3, respectively.

CS, as well as the fractions, was characterized for total carbohydrate content following the method described earlier by Dhople \& Bhosle (1987) and protein content described by Lowry et al. (1951). D-glucose and BSA were used as the standards for carbohydrate and protein analysis respectively. The larval assays with CS and its fractions were rationalized at

Table 1. Pseudomonas aeruginosa. Results of the tests employed to identify the bacterium. KIA/TSI: Kligler's Iron Agar/Triple Sugar Iron Agar; O-F glucose: oxidationfermentation text using glucose; + : positive; -:negative

\begin{tabular}{|c|c|}
\hline Test & Results \\
\hline Color & Cream \\
\hline Shape & Short rods \\
\hline Gram stain & - \\
\hline Motility & + \\
\hline Hugh Leifson's test & Aerobic oxidative \\
\hline Growth at pH 3.6 & - \\
\hline Growth at $4^{\circ} \mathrm{C}$ & - \\
\hline Growth at $41^{\circ} \mathrm{C}$ & + \\
\hline Indole & - \\
\hline Methyl red & - \\
\hline Simmons citrate & + \\
\hline $\mathrm{H}_{2} \mathrm{~S}(\mathrm{KIA} / \mathrm{TSI})$ & - \\
\hline Urease & - \\
\hline Phenylalanine deaminase & - \\
\hline Nitrate reduction & + \\
\hline Oxidase & + \\
\hline Catalase & + \\
\hline Denitrification & + \\
\hline Gelatin liquefaction & + \\
\hline Starch hydrolysis & - \\
\hline O-F glucose & Oxidative \\
\hline Arginine dihydrolase & + \\
\hline Alkaline phosphatase heat resistance & + \\
\hline Litmus milk (peptonization) & + \\
\hline \multicolumn{2}{|l|}{ Utilization of: } \\
\hline Glucose & + \\
\hline D-xylose & - \\
\hline D-ribose & + \\
\hline Mannitol & + \\
\hline Cellobiose & - \\
\hline D-mannose & - \\
\hline L-arabinose & - \\
\hline Lactose & - \\
\hline Maltose & - \\
\hline D-fructose & + \\
\hline m-inositol & - \\
\hline Sucrose & - \\
\hline D-galactose & - \\
\hline Acetamide & + \\
\hline
\end{tabular}


$50 \mu \mathrm{g} \mathrm{ml} \mathrm{m}^{-1}$ of carbohydrates and were carried out at different salinities $(15,25,35$ and $45 \%$ o).

Bacterial extract: The bacterium was extracted in butanol following the method described by Elyakov et al. (1996). This butanol-bacterial extract (BBE) was stored below $5^{\circ} \mathrm{C}$ for further use. The butanol extracted only low MW polar metabolites. A concentration of $50 \mu \mathrm{g} \mathrm{ml}^{-1}$ of BBE was used to examine its effect on the cyprid metamorphosis at 15, 25, 35 and $45 \%$.

The BF, CS, fractions and bacterial extract were also examined in the presence of $\mathrm{AE}\left(50 \mu \mathrm{g} \mathrm{ml} \mathrm{m}^{-1}\right)$.

Expt 2. This experiment was carried out at 35\%. It differs from Expt 1 as it was carried out with CS, fractions and bacterial extract $\left(50 \mu \mathrm{g} \mathrm{ml}^{-1}\right.$ ) without washing off the leachants; hence, the larvae were subjected to adsorbed (surface-bound) components as well as the leachants. The effect of AE (50 $\left.\mu \mathrm{g} \mathrm{ml}^{-1}\right)$ was similarly assessed.

Expt 3. The bacteria were grown in marine broth (MB), BSS, organically rich modified Vishniac's medium (MV) as described by Perkins (1973) and semi-solid culture (Abu et al. 1991). The CS were harvested by centrifugation $(20000 \times g$ for $30 \mathrm{~min})$ and subsequently sterile filtered $(0.22 \mu \mathrm{m}$, Millipore). They were then concentrated to one-tenth of the original volume in a stirred ultrafiltration cell (1000 MW cutoff, Amicon). The CS were characterized by estimating total carbohydrates and proteins. The larval assays were carried out at carbohydrate and protein concentrations of 25 and $50 \mu \mathrm{g} \mathrm{ml}^{-1}$, respectively. These CS, extracted using different nutritional media, i.e. CS(MB), CS(BSS), CS(MV) and CS(semi-solid), were examined at $35 \%$. They were also examined in the presence of AE $\left(25 / 50 \mu \mathrm{g} \mathrm{ml}^{-1}\right)$.

Semi-solid culture: Since the growth conditions used in the semi-solid culture are different from those of other cultures, the details are provided. For this, Pseudomonas aeruginosa cells grown in $\mathrm{MB}$ were washed with phosphate-buffered saline ( $\mathrm{pH}$ 7.3) and resuspended in the same buffer. Five milliliters of the washed suspension was added to a petri plate of marine agar that had been overlaid with a sterile dialysis membrane (8000 MW cut-off) presoaked in deionized water and rinsed with sterile PBS ( $\mathrm{pH} 7.3)$. After $24 \mathrm{~h}$, polycarbonate Nuclepore filters (25 mm, $0.4 \mu \mathrm{m}$ pore size) were introduced into the thin liquid layer on the surface of the dialysis membrane. To extract and purify the exopolymer, the membranes were removed and surface growth was scraped into a minimum amount of PBS. Sodium chloride was added to a final concentration of $0.4 \mathrm{M}$. In order to preserve the osmotic stability, glycerol was added to a final dilution of 1:24. The suspension was then agitated at $4^{\circ} \mathrm{C}$ overnight and centrifuged at $30000 \times g$ for $35 \mathrm{~min}$ at $4^{\circ} \mathrm{C}$. The recovered supernatant was dialysed (8000 MW cut-off) overnight against distilled water. The non-dialysable material was filtered through Whatman \#4 filter paper and lyophilized. The lyophilized material was redissolved in a minimum amount of distilled water and filtered through Whatman \#4 paper. The CS thus obtained was characterized by estimating total carbohydrates and proteins.

Expt 4. Extraction of bacterial EPS: For the extraction of EPS, the CS extracted under different nutritional conditions were treated with 5 volumes of absolute ethanol and left at $4{ }^{\circ} \mathrm{C}$ overnight. The precipitate (EPS) was recovered by centrifugation at $30000 \times$ $g$ for $15 \mathrm{~min}$ at $4{ }^{\circ} \mathrm{C}$, redissolved in distilled water, and treated with DNAse and RNAse A (1 to $2 \mu \mathrm{g} \mathrm{ml}^{-1}$ final concentration) for $3 \mathrm{~h}$ at $37^{\circ} \mathrm{C}$. The material was dialyzed (8000 MW cut-off) overnight at $4^{\circ} \mathrm{C}$ against distilled water and centrifuged at $30000 \times g$ for $20 \mathrm{~min}$ at $25^{\circ} \mathrm{C}$ to remove insoluble material. The supernatant was recovered and lyophilized. The EPS were evaluated for carbohydrate content and rationalized at a concentration of $50 \mu \mathrm{g} \mathrm{ml}^{-1}$ at $35 \%$. They were then subjected to the assays separately, as well as in the presence of AE $\left(50 \mu \mathrm{g} \mathrm{ml}^{-1}\right)$.

Fourier transformed infrared spectroscopy (FTIR). The major structural groups of the CS of the bacteria cultivated in different nutrient media, MW fractions and the bacterial extract were detected using FTIR.

Assay protocol. The settlement assays were carried out using Corning-430343 6-well multiwells. The multiwells were inoculated with BF, CS, fractions, bacterial EPS and bacterial extract. They were also assessed along with AE (3 replicates for each of the combination by taking 3 different batches of larvae and repeated thrice, $\mathrm{n}=9$ ). Controls were FSW (negative control) and AE (positive control). The inoculated multiwells were rinsed off after $3 \mathrm{~h}$ by repeated rinsing with autoclaved FSW under a laminar chamber except in Expt 2, where the mutiwells containing the dilutions were assessed along with the leachants (without washing off). Subsequently, 35 to 40 cyprids were introduced with $5 \mathrm{ml}$ of autoclaved FSW $(15,25,35$ and $45 \%$ salinity) as required. The settlement assays were monitored for a period of $4 \mathrm{~d}$ with an intermittent observation every day. Assay wells were maintained at $26 \pm 1^{\circ} \mathrm{C}$ (12:12 h light:dark cycle). The influence of $\mathrm{BF}, \mathrm{AE}$ and FSW was also investigated at 20 and $30 \pm 1^{\circ} \mathrm{C}$.

Statistical analysis. Data in the form of percentage of larval settlement were arcsine transformed to ensure normality of means and homogeneity of variances before statistical analysis. The influence of Pseudomonas aeruginosa, $\mathrm{CS}$, fractions and the bacterial extract in the presence and absence of AE on the metamorphosis of cyprids was evaluated using 1-way ANOVA (Sokal \& Rohlf 1981). A post ANOVA was performed using Scheffé's test $(\alpha=0.05)$. Those factors that did not meet the normality assumption were 


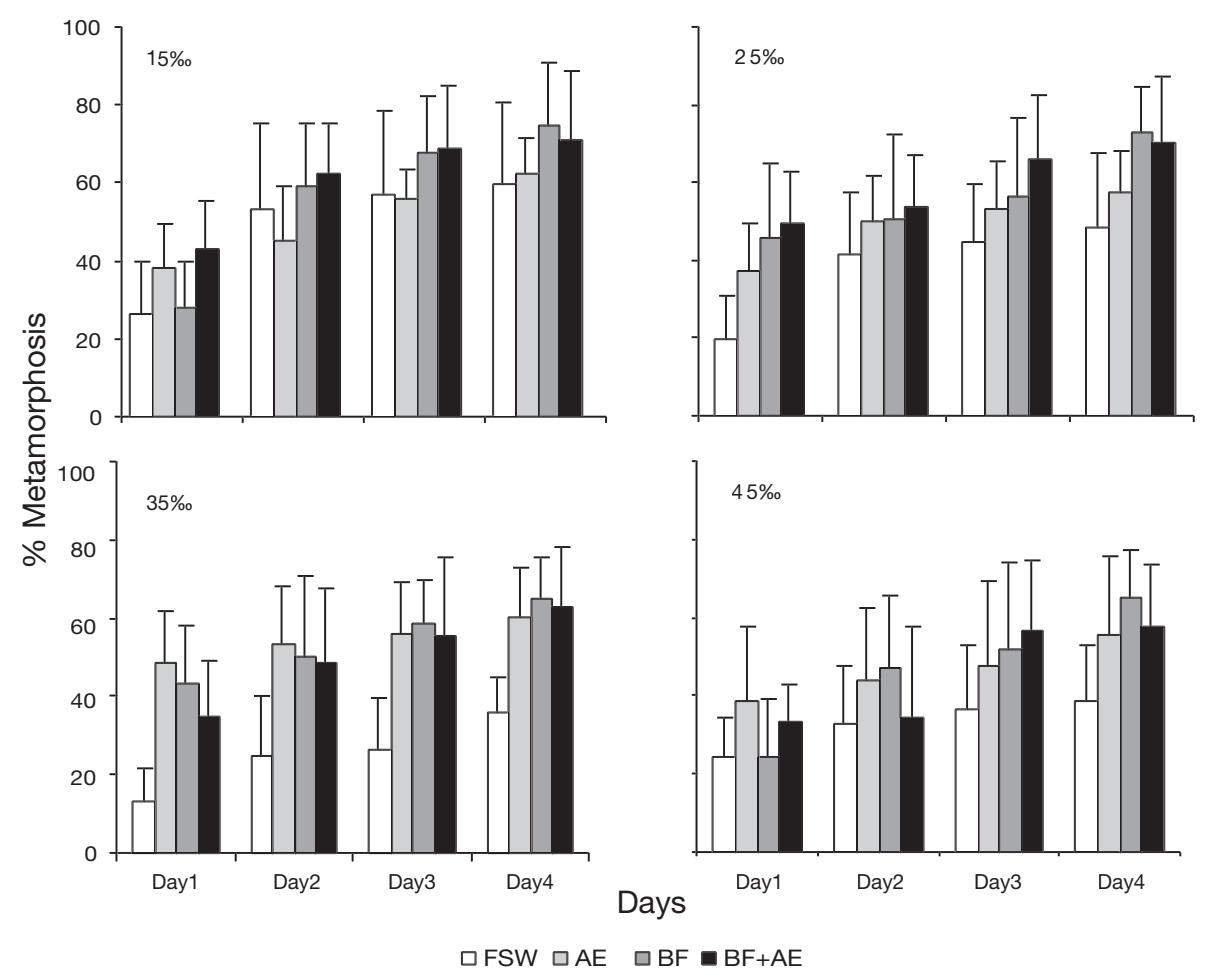

Fig. 2. Balanus amphitrite. Expt 1. Percentage metamorphosis of cyprids exposed to bacterial film (Pseudomonas aeruginosa) in the presence of AE at different salinities. Vertical lines indicate mean + SD. Abbreviations as in Fig. 1

analyzed using non-parametric statistical analysis such as Mann-Whitney $U$-test $(\alpha=0.025)$. The analysis was performed by transforming the values to ranks and was used to compare the means between the 2 treatments. Three-way ANOVA was performed to evaluate the influence of temperature and salinities with respect to $\mathrm{BF}, \mathrm{AE}$ and FSW on the cyprid metamorphosis. The data in Expt 1 were also subjected to cluster analysis in order to evaluate the influence of all the bacterial inducers on larval metamorphosis. The dissimilarity levels were measured through the squared Euclidean distance and group average method (Pielou 1984). The procedure shows the result of the clustering as a tree diagram or dendrogram. Squared Euclidean distance is used to measure the dissimilarity level. The intercluster distance is measured by the group average method. The $x$-axis groupings are based on the clusters that are dissimilar beyond the mid-point of the highest dissimilarity observed.

\section{RESULTS}

\section{Expt 1}

When the BF of Pseudomonas aeruginosa was assessed at $26^{\circ} \mathrm{C}$ and at different salinities, the cyprids metamorphosed at higher percentages than the con- trol (FSW) at 25 and 35\% (p $\leq 0.025$, Mann-Whitney), whereas at 15 and $45 \%$, metamorphosis was not facilitated (Fig. 2). The metamorphosis rates of the cyprids exposed to $\mathrm{BF}$ at different salinities were significantly different $(p \leq 0.01,1$-way ANOVA; $p \leq 0.05$, Scheffé's test). However, such differences were not evident with the aging of the films and cyprids (Table 2a). When assessed in the presence of AE, metamorphosis was facilitated irrespective of salinity differences (Fig. 2). The influence of bacteria in the presence of AE did not differ significantly with respect to salinity (Table 2b).

$\mathrm{BF}$ appeared to be the most influential in inducing the metamorphosis of cyprids when compared to AE at 20 and $30^{\circ} \mathrm{C}$ except at $45 \%$ (Fig. 3). At these temperatures, the influence of $\mathrm{BF}, \mathrm{AE}$ and FSW was almost similar at $45 \%$ and comparatively less than that observed at $26^{\circ} \mathrm{C}$. Three-way ANOVA indicated the differences between $\mathrm{BF}, \mathrm{AE}$ and FSW to be significant with respect to salinity and temperature at the end of Day 1, whereas on Day 4 no significant differences were observed (Table 3).

Cluster analysis indicated that the response of the cyprids to some of the bacterial cues that showed similarity in larval induction of metamorphosis at one salinity differed at the other (Fig. 4). At 15\%, BF and AE were similar in inducing larval metamorphosis, owing to which they formed 1 cluster, whereas at $25 \%$ o BF was 
Table 2. One-way ANOVA. Influence of Pseudomonas aeruginosa, culture supernatant (CS), CS fractions and butanol-bacterial extract (BBE) at different salinities on the metamorphosis of Balanus amphitrite cyprids. AE: adult extract; BF: bacterial film; CS1: MW < 10000 ; CS2: MW = 10000 to 30 000; CS3: MW > 30 000; Fs: Fischer constant; MS: mean of squares; ns: not significant; SS: sum of squares; err.: error. ${ }^{*} \mathrm{p} \leq 0.05 ;{ }^{* *} \mathrm{p} \leq 0.025 ;{ }^{* * *} \mathrm{p} \leq 0.01{ }^{*{ }^{* * * * *}} \mathrm{p} \leq 0.001$

\begin{tabular}{|c|c|c|c|c|c|c|c|c|c|c|c|c|c|c|}
\hline \multirow[t]{2}{*}{ Factor } & \multirow[t]{2}{*}{ df } & \multicolumn{3}{|c|}{ Day 1} & \multicolumn{3}{|c|}{ Day 4} & & \multicolumn{3}{|c|}{ Day 1} & \multicolumn{3}{|c|}{ Day 4} \\
\hline & & SS & MS & Fs & SS & MS & Fs & & SS & MS & Fs & SS & MS & Fs \\
\hline (a) BF $\quad$ Salinity & 3 & 1731 & 577 & $4.7^{* * *}$ & 502 & 167 & $0.8(\mathrm{~ns})$ & (b) $\mathrm{BF}+\mathrm{AE}$ & 509 & 170 & $2.2(\mathrm{~ns})$ & 372 & 124 & $0.4(\mathrm{~ns})$ \\
\hline Within sub-group err. & 32 & 3879 & 121 & & 6421 & 200 & & & 2420 & 76 & & 9547 & 298 & \\
\hline Total & 35 & 5610 & & & 6923 & & & & 2929 & & & 9919 & & \\
\hline (c) CS1 Salinity & 3 & 64 & 21 & $0.4(\mathrm{~ns})$ & 179 & 59 & $0.5(\mathrm{~ns})$ & (d) $\mathrm{CS} 1+\mathrm{AE}$ & 313 & 104 & $0.7(\mathrm{~ns})$ & 310 & 103 & $0.5(\mathrm{~ns})$ \\
\hline Within sub-group err. & 32 & 1387 & 43 & & 3405 & 106 & & & 4735 & 148 & & 6907 & 216 & \\
\hline Total & 35 & 1451 & & & 3584 & & & & 5048 & & & 7217 & & \\
\hline (e) CS2 Salinity & 3 & 174 & 58 & $0.6(\mathrm{~ns})$ & 1643 & 547 & $1.7(\mathrm{~ns})$ & (f) $\mathrm{CS} 2+\mathrm{AE}$ & 163 & 54 & $0.2(\mathrm{~ns})$ & 1533 & 511 & $1.4(\mathrm{~ns})$ \\
\hline Within sub-group err. & 32 & 2848 & 89 & & 9771 & 305 & & & 7162 & 224 & & 11894 & 372 & \\
\hline Total & 35 & 3022 & & & 11414 & & & & 7325 & & & 13427 & & \\
\hline (g) CS3 Salinity & 3 & 1399 & 466 & $7^{* * * * *}$ & 629 & 209 & $1.9(\mathrm{~ns})$ & (h) $\mathrm{CS} 3+\mathrm{AE}$ & 1649 & 550 & $3.3^{*}$ & 2810 & 937 & $4.3^{* *}$ \\
\hline Within sub-group err. & 32 & 2121 & 66 & & 3561 & 111 & & & 5303 & 166 & & 6919 & 216 & \\
\hline Total & 35 & 3520 & & & 4190 & & & & 6952 & & & 9729 & & \\
\hline (i) CS Salinity & 3 & 843 & 281 & $2.9^{*}$ & 1512 & 504 & $2.2(\mathrm{~ns})$ & (j) $\mathrm{CS}+\mathrm{AE}$ & 480 & 160 & $0.6(\mathrm{~ns})$ & 2477 & 826 & $2.8(\mathrm{~ns})$ \\
\hline Within sub-group err. & 32 & 3063 & 95 & & 7235 & 226 & & & 9137 & 285 & & 9299 & 291 & \\
\hline Total & 35 & 3906 & & & 8747 & & & & 9617 & & & 11776 & & \\
\hline (k) BBE Salinity & 3 & 1326 & 442 & $4.4^{* *}$ & 570 & 190 & $1.6(\mathrm{~ns})$ & (l) $\mathrm{BBE}+\mathrm{AE}$ & 160 & 53 & $0.4(\mathrm{~ns})$ & 2052 & 684 & $3.1^{*}$ \\
\hline Within sub-group err. & 32 & 3223 & 101 & & 3760 & 117 & & & 3884 & 121 & & 7016 & 219 & \\
\hline Total & 35 & 4549 & & & 4330 & & & & 4044 & & & 9068 & & \\
\hline
\end{tabular}

most dissimilar to the rest of the cues. At $35 \%$, BF and AE were highly dissimilar to rest of the bacterial cues, whereas at $45 \%$ BF and CS1 showed a similar response (Fig. 4, Day 1). The response differed as the cyprids and the cues aged (Fig. 4, Day 4).

The response of cyprids toward bacterial CS varied with the fractions containing different MW substances. A significant difference in metamorphosis inducement with respect to salinity was seen only with CS3 ( $\mathrm{p} \leq$ 0.001 , 1-way ANOVA; $p \leq 0.05$, Scheffé's test) on Day 1, whereas on Day 4 these differences were not significant (Table $2 \mathrm{~g}$ ). The percentage of larvae metamorphosing in response to CS2 at 15 and $25 \%$ and CS

Table 3. Balanus amphitrite. Three-way ANOVA. Influence of temperature $\left(20,26\right.$ and $\left.30^{\circ} \mathrm{C}\right)$ and salinities $(15,25,35$ and $45 \%$ o) with respect to treatments $\mathrm{BF}, \mathrm{AE}$ and FSW) on the metamorphosis of B. amphitrite cyprids on Day 1 and Day $4 .{ }^{* *} \mathrm{p} \leq 0.025 ;{ }^{* * *} \mathrm{p} \leq 0.01$. Abbreviations as in Table 2

\begin{tabular}{|c|c|c|c|c|c|c|c|}
\hline \multirow[t]{2}{*}{ Factor } & \multirow[t]{2}{*}{$\mathrm{df}$} & \multicolumn{3}{|c|}{ Day 1} & \multicolumn{3}{|c|}{ Day 4} \\
\hline & & SS & MS & Fs & SS & MS & Fs \\
\hline A (temperature) & 2 & 756 & 378 & & 4231 & 2115 & \\
\hline B (salinity) & 3 & 208 & 104 & & 689 & 344 & \\
\hline $\mathrm{C}$ (treatments) & 2 & 259 & 86 & & 517 & 172 & \\
\hline $\mathrm{A} \times \mathrm{C}$ & 4 & 189 & 47 & $6^{* * *}$ & 86 & 21 & 2 (ns) \\
\hline $\mathrm{A} \times \mathrm{B}$ & 6 & 105 & 17 & $2.2(\mathrm{~ns})$ & 146 & 24 & $2.2(\mathrm{~ns})$ \\
\hline $\mathrm{C} \times \mathrm{B}$ & 6 & 199 & 33 & $4.3^{* *}$ & 163 & 27 & 2.5 (ns) \\
\hline $\mathrm{A} \times \mathrm{B} \times \mathrm{C}$ & 12 & 94 & 8 & & 130 & 11 & \\
\hline Total & 35 & 1810 & & & 5962 & & \\
\hline
\end{tabular}

at $35 \%$ was higher than other fractions at the end of Day 1 (Fig. 5). However, neither CS2 nor CS was as inductive as $\mathrm{AE}$ at these salinities. At $45 \%$, the fraction CS3 and CS were as effective as AE in provoking metamorphosis of cyprids. In summary, the higher MW fraction of the CS was inductive at higher salinity. When the fractions were assessed in the presence of $\mathrm{AE}$ the metamorphosis rates increased. However, significant differences with respect to salinities were observed only with CS3 (Table 2h).

Bacterial extract showed ketonic compounds as indicated by FTIR, and their influence varied with salinity. The inhibitory effect of the extract at 15 and $35 \%$ was nullified in the presence of AE (Fig. 6).

A marginal increase in the metamorphosis rates was observed with the aging of the cyprids and the settlement cues.

\section{Expt 2}

When the surface-bound components of bacterial extract were assessed along with the leachants, a 2-fold increase in the metamorphosis rates was observed, where surface-bound components alone were inhibitory $(\mathrm{p} \leq 0.025$, Mann-Whitney). The leachants of fraction CS1 resulted in a decrease in the metamorphosis rates to as low as $4.5 \%$ when assessed along with its adsorbed components (Fig. 7). 

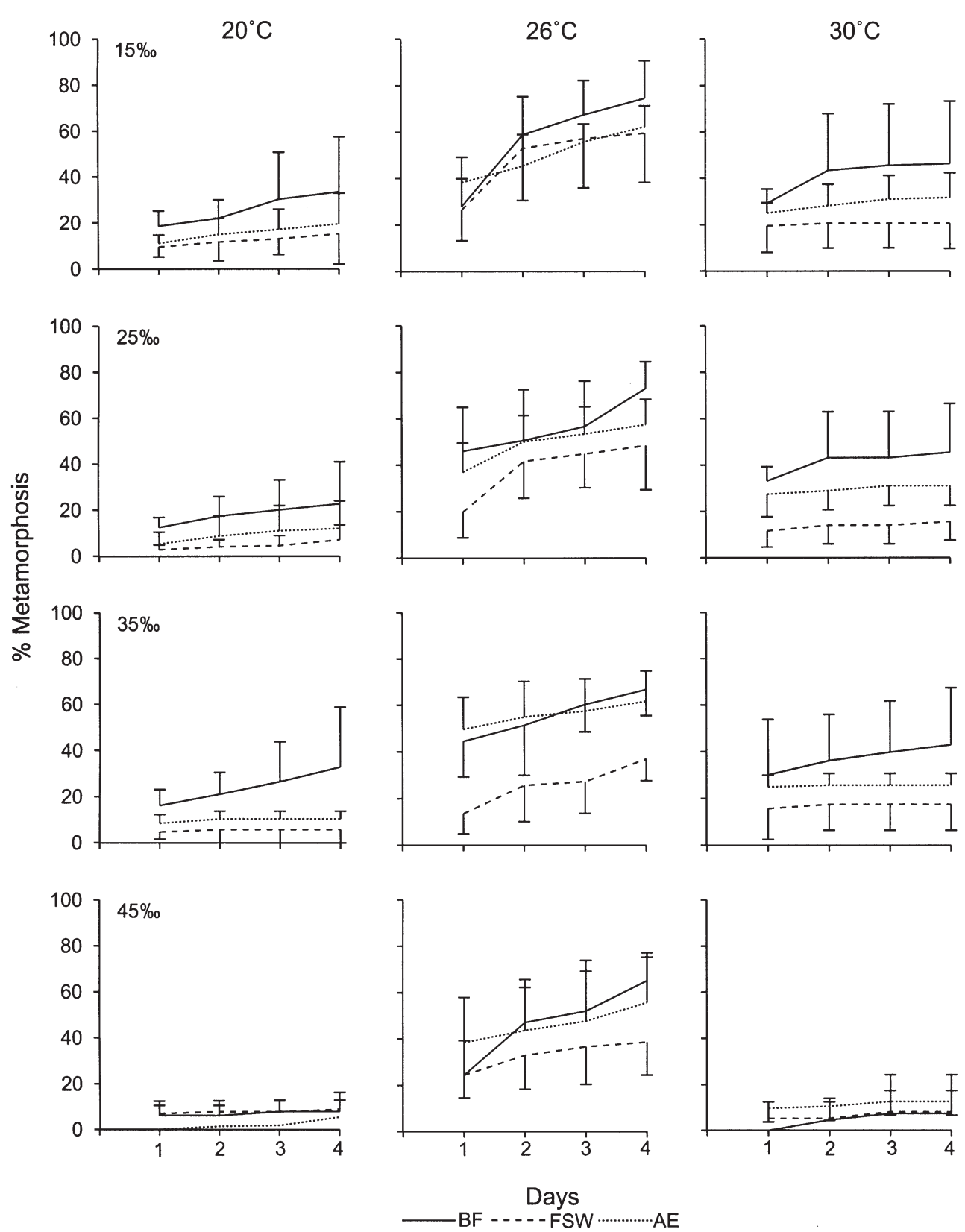

Fig. 3. Balanus amphitrite. Expt 1. Percentage metamorphosis of cyprids exposed to BF, FSW and AE at different salinities and temperatures. Vertical lines indicate mean \pm SD. Abbreviations as in Fig. 1

\section{Expt 3}

Pseudomonas aeruginosa cultivated in BSS, MB and MV resulted in CS with higher carbohydrate content, whereas those extracted using semi-solid culture showed higher protein content.

The larvae metamorphosed at higher percentages when exposed to CS obtained by semi-solid culture than those extracted using other nutritional media at a protein concentration of $25 \mu \mathrm{g} \mathrm{ml}^{-1}$. The differences between these supernatants were highly significant ( $p \leq 0.001,1$-way ANOVA; $p \leq 0.05$, Scheffé's test). An increase in protein concentration to $50 \mu \mathrm{g} \mathrm{ml}^{-1}$ resulted in non-significant differences (Table 4a). At this concentration CS produced by semi-solid culture showed an inhibition. At the end of Day 4, there was no significant difference in the response of the CS to cyprid metamorphosis at a carbohydrate concentration of $25 \mu \mathrm{g} \mathrm{ml}^{-1}$. Except for the CS produced by semi-solid culture, no other CS was comparable with $\mathrm{AE}$ or $\mathrm{BF}$ 


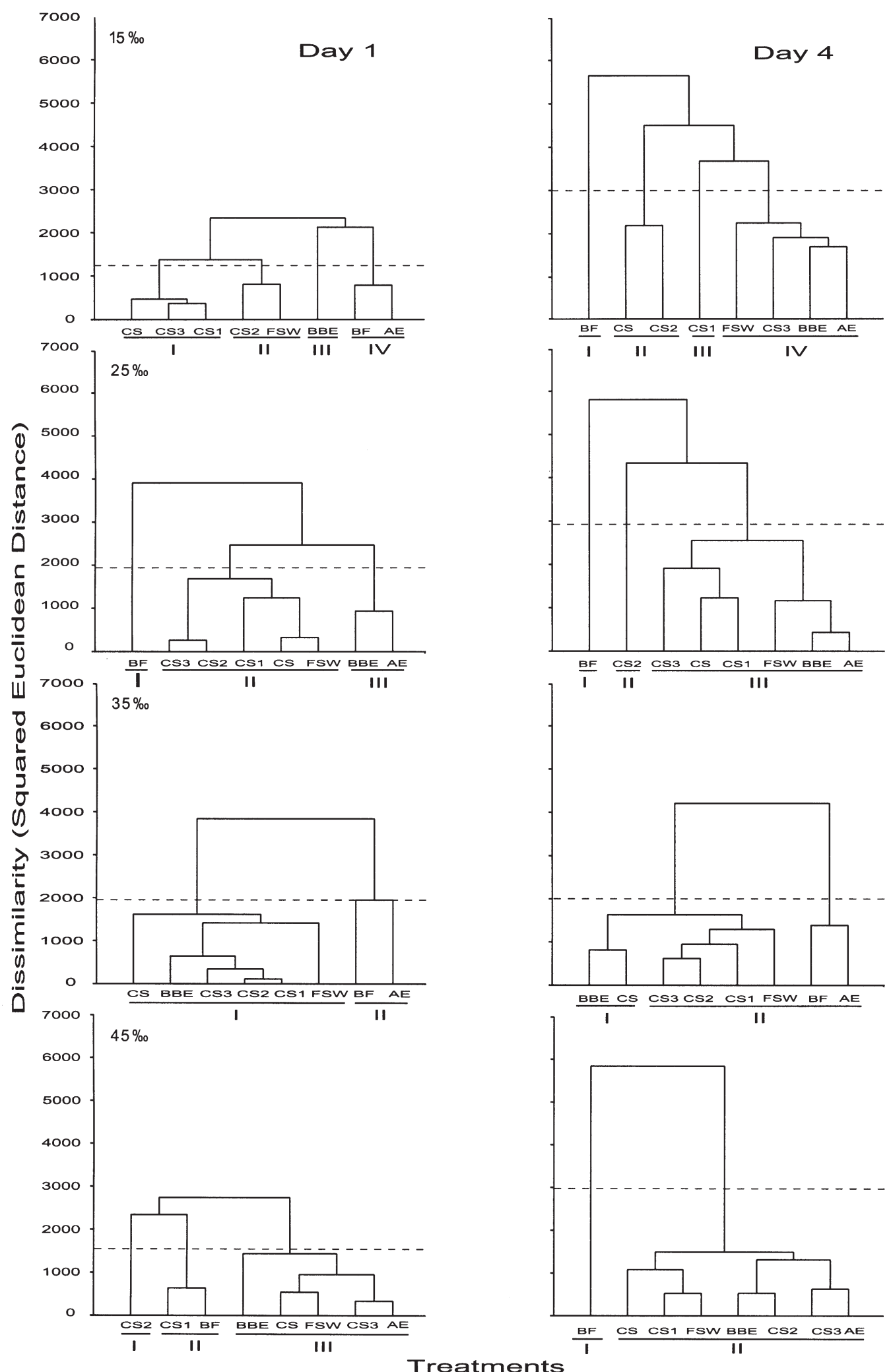

Fig. 4. Balanus amphitrite. Expt 1. Dendrograms showing the dissimilarity between different bacterial inducers (treatments) toward metamorphosis of cyprids on Days 1 and 4. Abbreviations as in Fig. 1. (The $x$-axis groupings are based on the clusters that are dissimilar beyond the mid-point of the highest dissimilarity observed) 

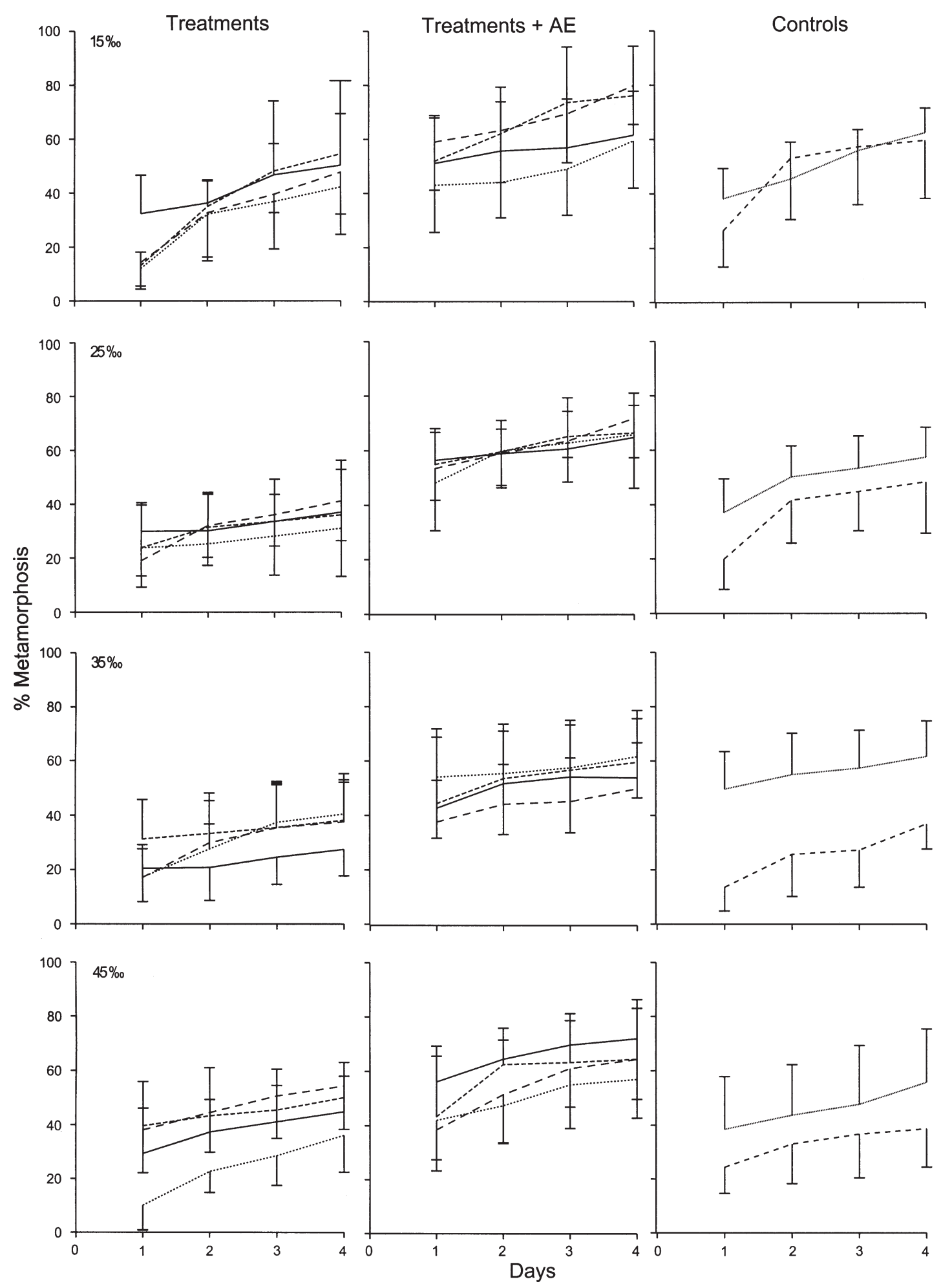

…….....CS1-CS2----CS3---.-.CS

Fig. 5. Balanus amphitrite. Expt 1. Percentage metamorphosis of cyprids in response to CS and its fractions (treatments) obtained from the bacteria grown in basal salt solution (BSS) in the presence and absence of AE at different salinities. Vertical lines indicate mean $\pm \mathrm{SD}$. Abbreviations as in Fig. 1 


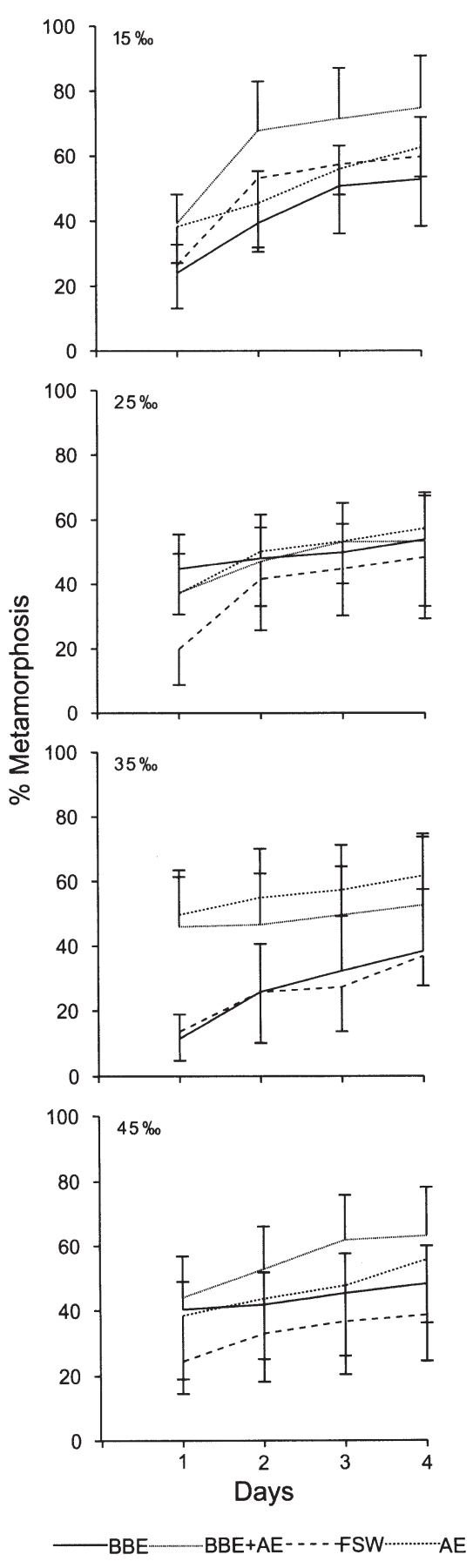

Fig. 6. Balanus amphitrite. Expt 1. Percentage metamorphosis of cyprids exposed to BBE at different salinities. Vertical lines indicate mean \pm SD. Abbreviations as in Fig. 1

(Fig. 8b,e). Mann-Whitney $U$-test showed no significant difference between $\mathrm{BF}, \mathrm{AE}$ and the CS extracted by semi-solid culture.

When these CS were assessed in the presence of $A E$, significant variations in metamorphosis were observed at a carbohydrate and protein concentration of 50 and

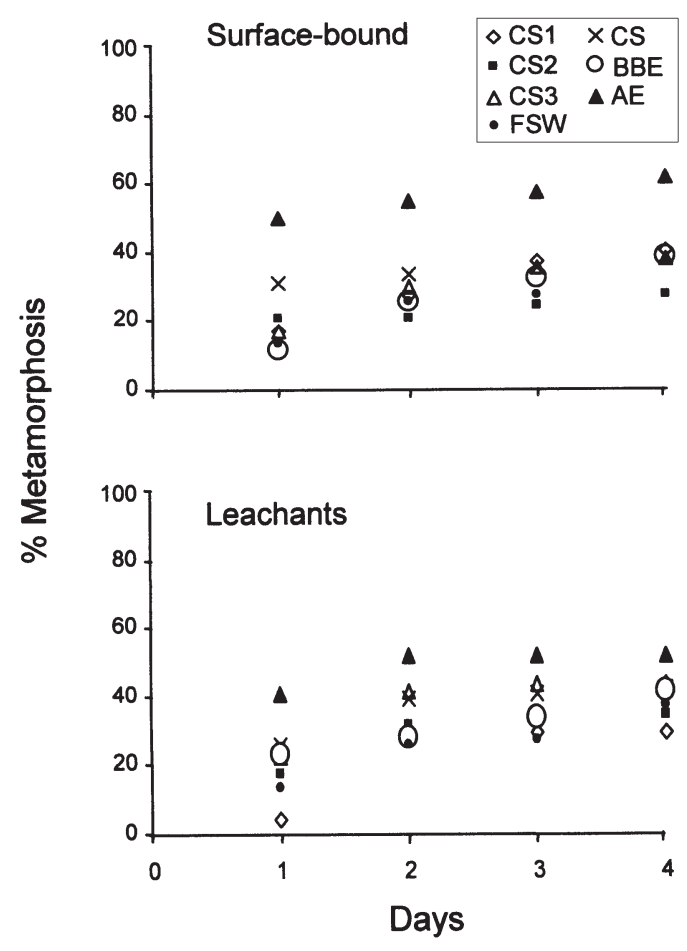

Fig. 7. Balanus amphitrite. Expt 2. Percentage metamorphosis of cyprids and bacterial inducers (surface-bound) used in Expt 1 in the presence of leachants at 35\%. Abbreviations as in Fig. 1

$25 \mu \mathrm{g} \mathrm{ml}^{-1}$, respectively, at the end of Day 1 (Table 4b). However, Day 4 observations indicated non-significant differences between CS only at a protein concentration of $50 \mu \mathrm{g} \mathrm{ml}^{-1}$.

\section{Expt 4}

The EPS obtained from the bacteria grown in semisolid culture showed high protein content, whereas those obtained from BSS, MB and MV media were mainly carbohydrates. The EPS obtained from BSS exhibited similar metamorphosis to that shown by bacteria and $\mathrm{AE}$ at $35 \%$ (Fig. 9).

FTIR

The FTIR spectra of CS1, CS2, CS3 and CS revealed characteristic strong peaks around 3550 to 3200,1640 and 1076 to $1122 \mathrm{~cm}^{-1}$ for $\mathrm{O}-\mathrm{H}$ stretching, $\mathrm{C}=\mathrm{O}$ stretching and $\mathrm{C}-\mathrm{O}$ stretching. The structural identity of CS1, CS2, CS3 and CS from FTIR results was mainly of carbohydrates. Similar results were obtained with the CS of MB and MV media (Fig. 10).

CS of semi-solid culture and the bacterial extract revealed strong peaks at 1624 and $1647 \mathrm{~cm}^{-1}$ for N-H bend 
Culture supernatants
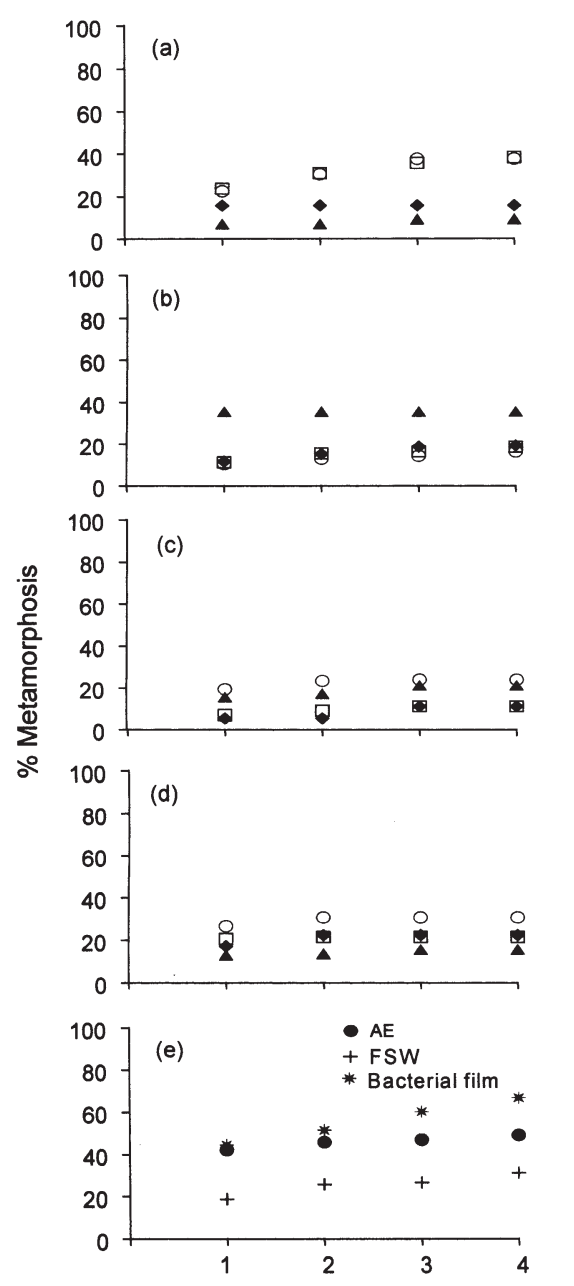

Days
Culture supernatants $+\mathrm{AE}$
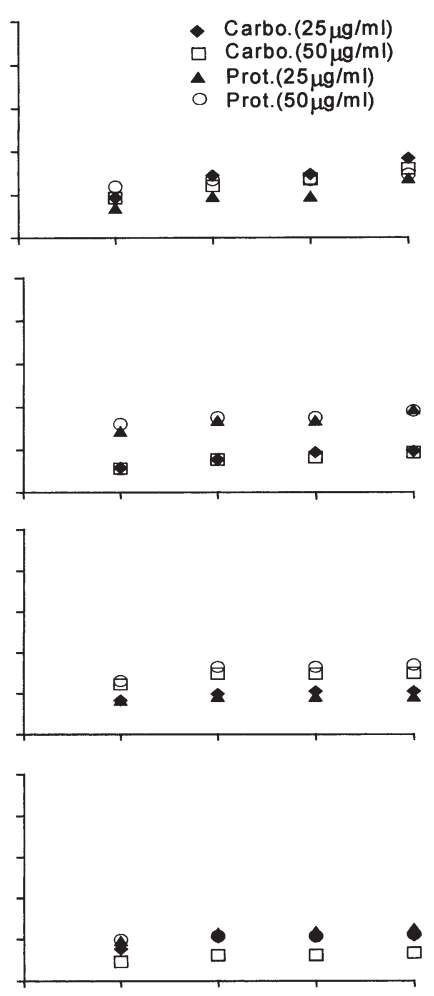

Fig. 8. Balanus amphitrite. Expt 3. Percentage metamorphosis of cyprids exposed to CS obtained by growing the bacteria under different nutritional media at $35 \%$ in the presence and absence of AE. (a) CS(BSS);

(b) CS(semi-solid); (c) CS(MV) (d); CS(MB); (e) controls. Carbo: carbohydrate; Prot: protein; other abbreviations as in Fig.1 produce different compounds at different salinities that result in differential binding with the cyprid's temporary adhesive. The strength of these interactions determines how well a cyprid adheres to a filmed surface (Yule \& Crisp 1983, Neal \& Yule 1992). Also, changes in environmental conditions can turn on the previously unexpressed genes (Dagostino et al. 1990, Davies et al. 1993, Davies \& Geesey 1995) and stimulate changes in bacterial morphology (Dalton et al. 1994). The variations in larval behavior in response to salinity and temperature thus can be attributed to alteration in metabolic activities and expression of different cell surface organic molecules. These surfaceassociated specific biochemicals not only may function in the role of stimulating or inhibiting larvae but also may change the surface chemistry in a more general fashion. By doing so, they either mask important signals or block the receptors responsible for eliciting the larval responses (Maki 1999). The major bacterially derived chemicals, which are used as cues for settlement by many invertebrate larvae, include waterborne products (Neumann 1979, Fitt et al. 1990) and substances associated with the bacterial cell surface (Müller 1973, Kirchman et al. 1982a,b, Maki \& Mitchell 1985, Schmahl 1985, Szewzyk et al. 1991). It has been reported that a metabolically active BF is needed to maintain the putative cue at a concentration that surpasses the threshold for induction of larval settlement (Lau \& Qian 2001). Maki et al. (1994) reported that Deleya marina films on polystyrene dishes showed a negative effect on attachment of Balanus amphitrite, whereas on tissue-culture polystyrene or borosilicate glass it did not. Hence, the composition of the substratum can influ-

and were proteinaceous. In the case of semi-solid CS, the presence of terpenoids and steroids was evidenced from infrared absorption at 1475 and $1363.6 \mathrm{~cm}^{-1}$; the spectra also indicated the presence of unsaturation evident from $\mathrm{C}-\mathrm{H}$ bending vibrations located around 1000 and $900 \mathrm{~cm}^{-1}$. Bacterial extract showed peaks at 1715 and $1675 \mathrm{~cm}^{-1}$, characteristic of ketones.

\section{DISCUSSION}

The facilitation of metamorphosis by Pseudomonas aeruginosa depended on the salinity and temperature. Maki et al. (1990) suggested that a bacterium might ence the effect a bacterial species has on the attachment of cyprids (O'Connor \& Richardson 1998).

When the BF was examined in the presence of $A E$, metamorphosis was facilitated irrespective of the salinity differences. The BF may contain substances (antagonists) for which a particular receptor site does have an affinity, but whose binding to that site causes a smaller or no effect. In the presence of a particular concentration of an active substance (agonist), such as AE, a positive effect may be obtained by competitive antagonism (Musch 1996). The involvement of chemosensory or internal neuronal processes as early transducers and mediators of recruitment process is suggested by the fact that $\gamma$-aminobutyric acid (GABA) and GABA 
Table 4. Balanus amphitrite. (a) One-way ANOVA: Influence of CS extracted by 4 different extraction protocols at 2 different concentrations of carbohydrates and proteins on the metamorphosis of B. amphitrite cyprids. (b) One-way ANOVA: influence of CS extracted by 4 different extraction protocols at 2 different concentrations of carbohydrates and proteins in the presence of AE on the cyprid metamorphosis of $B$. amphitrite. ${ }^{*} \mathrm{p} \leq 0.05 ;{ }^{* *} \mathrm{p} \leq 0.025 ;{ }^{* * *} \mathrm{p} \leq 0.01 ;{ }^{* * * *} \mathrm{p} \leq 0.005_{;}{ }^{* * * * *} \mathrm{p} \leq 0.001$. Abbreviations as in Table 2

\begin{tabular}{|c|c|c|c|c|c|c|c|c|c|c|c|c|c|}
\hline \multirow[t]{2}{*}{ Factor } & \multirow[t]{2}{*}{ df } & \multicolumn{3}{|c|}{$\begin{array}{c}25 \mu \mathrm{g} \mathrm{m}^{-1} \\
\text { (carbohydrates) }\end{array}$} & \multicolumn{3}{|c|}{$\begin{array}{c}50 \mu \mathrm{g} \mathrm{ml}^{-1} \\
\text { (carbohydrates) }\end{array}$} & \multicolumn{3}{|c|}{$\begin{array}{c}25 \mu \mathrm{g} \mathrm{ml}^{-1} \\
\text { (proteins) }\end{array}$} & \multicolumn{3}{|c|}{$\begin{array}{c}50 \mu \mathrm{g} \mathrm{ml}^{-1} \\
\text { (proteins) }\end{array}$} \\
\hline & & SS & MS & Fs & SS & MS & Fs & SS & MS & Fs & SS & MS & Fs \\
\hline \multicolumn{14}{|l|}{ (a) } \\
\hline \multicolumn{14}{|l|}{ Day 1} \\
\hline $\mathrm{CS}$ & 3 & 258 & 86 & $4^{* *}$ & 588 & 196 & $3.6^{* *}$ & 1455 & 485 & $9.9^{* * * * *}$ & 448 & 149 & $2.7(\mathrm{~ns})$ \\
\hline Within sub-group err. & 32 & 698 & 21.8 & & 1711 & 53.5 & & 1562 & 48.8 & & 1751 & 54.7 & \\
\hline Total & 35 & 956 & & & 2299 & & & 3017 & & & 2199 & & \\
\hline \multicolumn{14}{|l|}{ Day 4} \\
\hline $\mathrm{CS}$ & 3 & 227 & 75.5 & $1.7(\mathrm{~ns})$ & 1297 & 432 & $7.07^{* * * * *}$ & 1204 & 401 & $7.5^{* * * * *}$ & 831 & 277 & $4.53^{* * *}$ \\
\hline Within sub-group err. & 32 & 1437 & 45 & & 1955 & 61.1 & & 1701 & 53.2 & & 1955 & 61.1 & \\
\hline Total & 35 & 1664 & & & 3252 & & & 2905 & & & 2786 & & \\
\hline \multicolumn{14}{|l|}{ (b) } \\
\hline \multicolumn{14}{|l|}{ Day 1} \\
\hline $\mathrm{CS}$ & 3 & 82 & 27.2 & $0.5(\mathrm{~ns})$ & 449 & 150 & $4.1^{* *}$ & 392 & 130 & $4.7^{* * *}$ & 271 & 90 & $1.4(\mathrm{~ns})$ \\
\hline Within sub-group err. & 32 & 1665 & 52 & & 1164 & 36.4 & & 873 & 27.3 & & 2030 & 63.4 & \\
\hline Total & 35 & 1747 & & & 1613 & & & 1265 & & & 2301 & & \\
\hline \multicolumn{14}{|l|}{ Day 4} \\
\hline $\mathrm{CS}$ & 3 & 1028 & 342 & $4.6^{* * *}$ & 1182 & 394 & $3.8^{* *}$ & 695 & 232 & $6.7^{* * * *}$ & 491 & 164 & $1.7(\mathrm{~ns})$ \\
\hline Within sub-group err. & 32 & 2390 & 75 & & 3277 & 102 & & 1109 & 35 & & 2955 & 92.4 & \\
\hline Total & 35 & 3418 & & & 4459 & & & 1804 & & & 3446 & & \\
\hline
\end{tabular}

analogs are potent inducers of settlement, attachment and metamorphosis (Morse 1984a,b, 1985, 1990, Pawlik 1990, Morse 1991a,b). Recently, Yamamoto et al. (1995) reported that a protein-kinase C (PKC) signal transduction system plays an important role in the metamorphosis of Balanus amphitrite cyprids. Clare et al. (1995) provided evidence for the involvement of cyclic AMP (cAMP) in the settlement of this species. Yamamoto et al. (1996) have also reported that 5-hydroxytryptamine (5-HT) is involved in the larval settlement of barnacles. The need to characterize and distinguish the receptors, which act via such signaling systems on particular settlement cues, is apparent.

Previous studies have reported increases in invertebrate larval recruitment with aged and more heavily filmed surfaces (Wieczorek et al. 1995, Keough \& Raimondi 1995, 1996). In contrast, Maki et al. (1990) demonstrated that a $3 \mathrm{~d}$ old natural biofilm, but not $1 \mathrm{~d}$ old biofilm, inhibited barnacle larvae. Avelin Mary et al. (1993) found that all Vibrio sp. films and most other isolates from biofilms associated with Balanus amphitrite were inhibitory and no film stimulated barnacle settlement. In another study (Wieczorek et al. 1995) the 'older' films (comprising larger proportions of the shape category 'Vibrios') clearly facilitated settlement. Pseudomonas fluorescence and Alteromonas macleodii films yielded weak and inconsistent effects on cyprid attachment of B. amphitrite. Despite variability between assays, bacterial effects on larval attach-

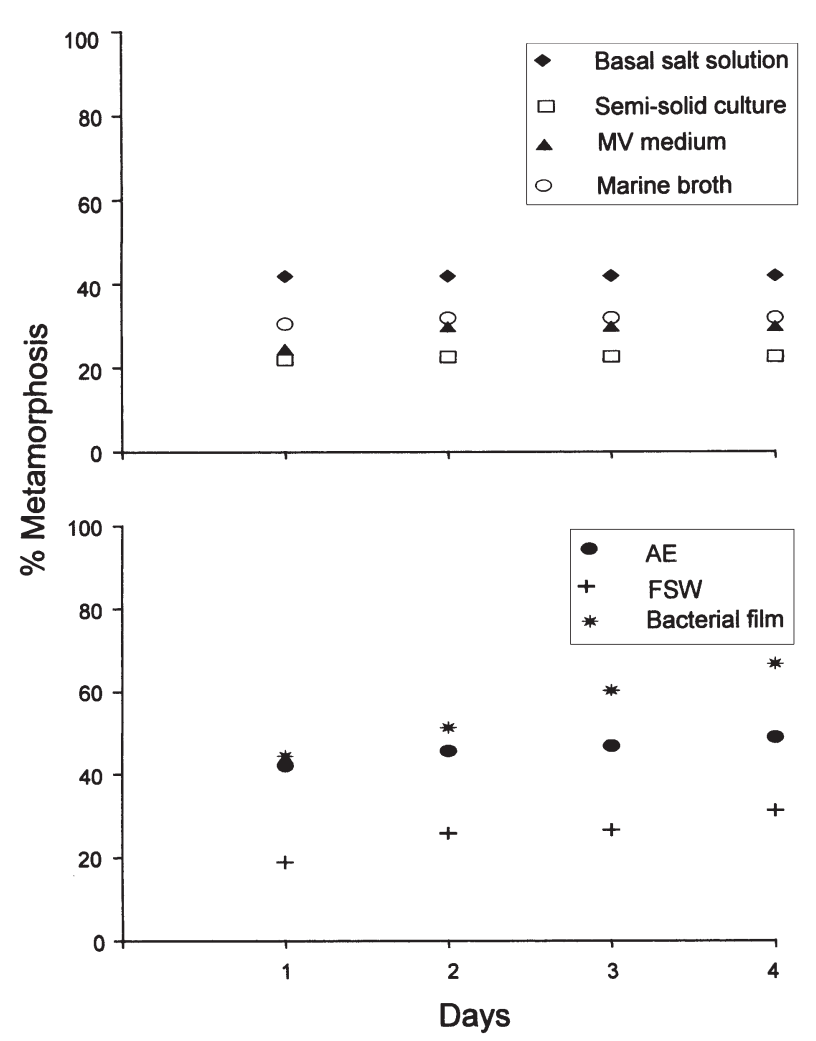

Fig. 9. Balanus amphitrite. Expt 4. Percentage metamorphosis of cyprids exposed to bacterial exopolysaccharides obtained after growing the bacteria under different nutritional conditions at $35 \%$. Abbreviations as in Fig. 1 

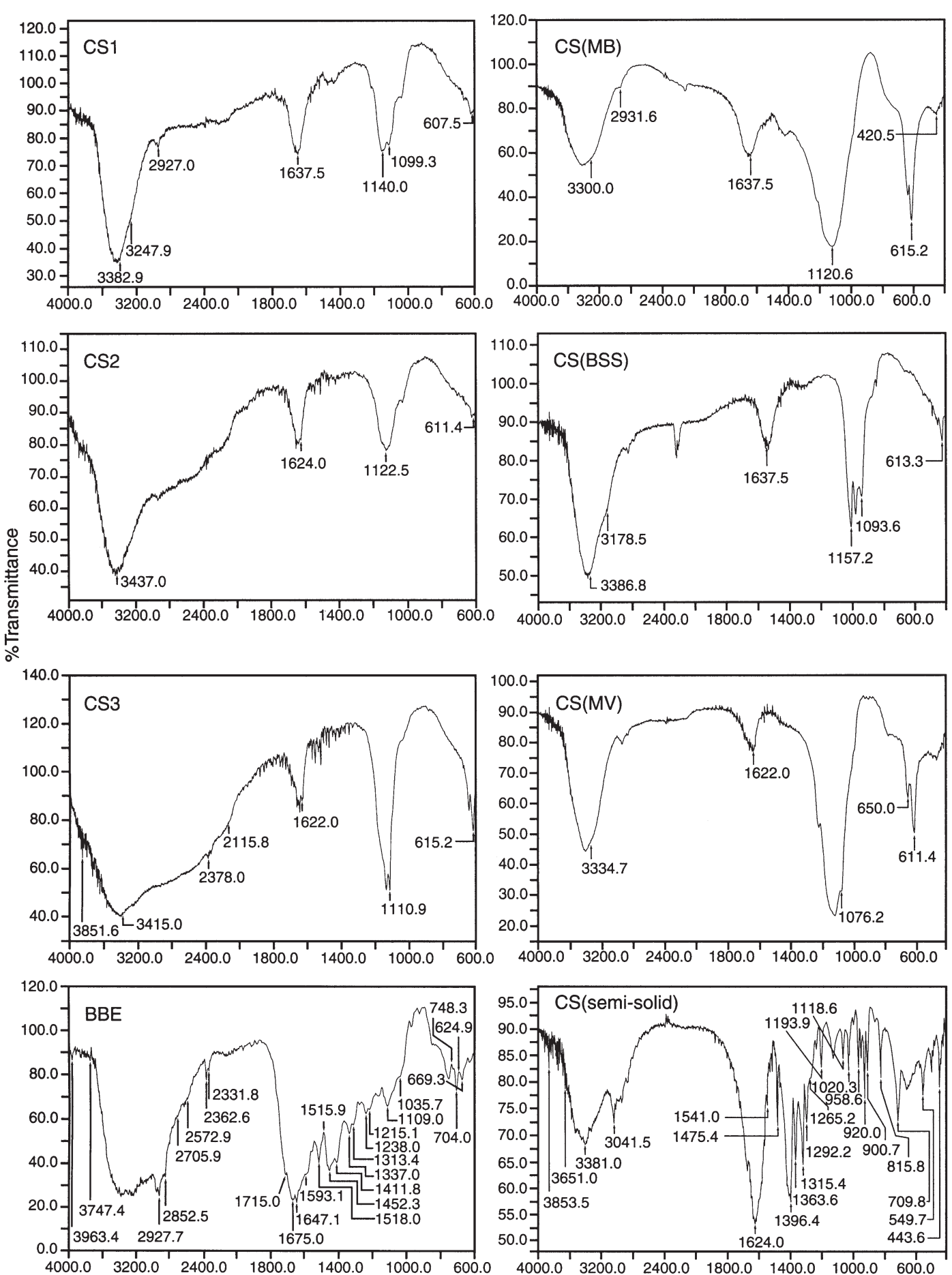

Wave number $\left(\mathrm{cm}^{-1}\right)$

Fig. 10. Fourier transformed infrared spectroscopy (FTIR) spectra of culture supernatants, fractions and the bacterial extract. AE was the positive control and FSW the negative control. Abbreviations as in Fig. 1

ment within a particular assay generally were consistent for the duration of the assay (up to a week) (O'Connor \& Richardson 1998). In the present study, although the facilitation of metamorphosis by P. aerug- inosa initially depended upon the salinity and temperature, the differences were not significant as the films and the cyprids aged. The aged film of $P$. aeruginosa promoted metamorphosis of cyprids at all salinities and 
temperatures. There was no significant difference in the bacterial multiplication with respect to salinity and temperature on Day 4. Although the BF promoted metamorphosis, the inability of all the cyprids to show a similar response can be attributed to their physiological conditions. The nutritional and environmental conditions seem to jointly determine the energy status of the larvae (Anil \& Kurian 1996, Anil et al. 2001). The cyprids that metamorphosed in response to the BF may be the ones that were physiologically fit. Earlier studies have shown that larval age is known to affect settlement where the older cyprids responded more readily to external cues (Rittschof et al. 1984, Crisp 1988, Satuito et al. 1997), presumably due to a decline in their energy reserves and thus physiological quality.

Maki et al. (1988) reported that exopolymers produced by the bacteria were involved in the attachment response of the larvae, the composition of which influences subsequent fouling by the invertebrate larvae, presumably by providing chemical cues for settlement. Although several studies have been carried out on the metamorphosis induction of the cyprid larvae, few have tested 2 or more factors on settlement (Pawlik 1992, Anil et al. 1997). The CS from stationary-phase cultures of Deleya marina consistently retarded cyprid attachment compared to attachment observed on control polystyrene petri dishes, but not glass vials (O'Connor \& Richardson 1998). In this investigation the CS containing the extracellular materials was fractionated into different MW categories, which were characterized in terms of protein and carbohydrates. The structural identity of CS1, CS2, CS3 and CS from FTIR results was mainly that of carbohydrates. The influence of CS and its fractions on the metamorphosis of cyprids also varied with the salinity. At lower salinity CS3 and CS1 did not induce metamorphosis, while CS2 promoted metamorphosis; however, the response of the CS was negative. The promotive effect of CS2 thus seems to be masked, rendering CS ineffective in provoking larval settlement. At $45 \%$, CS3 and CS induced maximum metamorphosis comparable to that of AE. The response of cyprids to bacterial supernatants can thus be attributed to the activity of specific MW compounds.

The leachants of the CS and its fractions were associated with a decrease in the metamorphosis rates, whereas the low MW fraction CS1 proved to be the most inhibitory. The interaction of sugars with water is highly specific and depends strongly on the stereoisomerism of the hydroxyl group (Maggio et al. 1985, Kuttenreich et al. 1988). The bacterial supernatants obtained from the bacteria grown in BSS were mainly carbohydrates. The differences in metamorphosis induction by them with respect to salinity may be the result of positional effect due to isomerism.
The EPS obtained from the bacteria grown in BSS exhibited similar metamorphosis effects to that of bacteria and $\mathrm{AE}$, and hence may be a responsible surfacebound component of the $\mathrm{BF}$, which supplied positive cues for the settling cyprids. The settlement of Janua sp. larvae was lectin mediated and involved bacterial EPS, where lectins on the larval surface are proposed to recognize and bind to the bacterial polymer containing glucose (Kirchman et al. 1982a,b). The extent of attachment of Ciona intestinalis larvae was also increased by the EPS produced by the bacteria (Szewzyk et al. 1991).

The bacterial extract was proteinaceous, showing the presence of ketonic compounds, and its influence varied with salinity. The inhibitory effect of the extract was nullified in the presence of AE. The leachants of the bacterial extract showed a 2 -fold increase in the metamorphosis rates where only surface-bound components were inhibitory. The bacterium was extracted in n-butanol, which extracted only low MW polar metabolites. The reason that surface-bound components of the bacterial extract did not provoke metamorphosis could be its highly polar nature, resulting in diffusion into the surrounding water in the multiwell. The variation in response of the surface-bound compounds of the extract at other salinities can also be related to the same reason and needs further validation. The increased detection of the bacterial extract in solution also suggests the role of the fourth antennular segment with its impressive array of sensory setae (Gibson \& Nott 1971, Clare \& Nott 1994) involving the olfactory receptors. In oysters, low MW peptides with arginine at the $\mathrm{C}$-terminal were identified as a natural water-soluble cue inducing settlement (Zimmer-Faust \& Tamburri 1994). Rittschof (1985) partially purified water-soluble peptides (3000 to $5000 \mathrm{Da}$ ) released by adult conspecifics, which initiated attachment by larvae of Balanus amphitrite. The possible involvement of ketonic compounds in altering the response of the bacterial extract cannot be ruled out.

The nutrient status of the bacteria was found to influence the quality and chemical composition of the CS containing the extracellular materials. Although the MB consisted mainly of peptic digest of animal tissue and the yeast extract, the CS was mainly carbohydrate in nature.

The CS obtained by semi-solid culture was proteinaceous and showed the presence of terpenoids and steroids. The degree of inducement by this was greater than the supernatant obtained from bacteria using any other nutrient media at a protein concentration of $25 \mathrm{\mu g} \mathrm{ml}^{-1}(\mathrm{p} \leq 0.001)$. An increase in protein concentration to $50 \mu \mathrm{g} \mathrm{ml}^{-1}$ resulted in inhibition of metamorphosis. The CS isolated from cells growing in a semisolid environment also more closely approximates the 
natural environment existing between a bacterium and its substratum (Abu et al. 1991). According to Boyle \& Reade (1983), such conditions may be similar to the effects of exposure to intertidal zones. The response of the cyprids to bacteria and its products seems to be regulated by both contact chemoreception and olfaction, which depend on the properties of the settlementinducing compounds.

Acknowledgements. We are grateful to Dr. E. Desa, Director of the National Institute of Oceanography, for his support and encouragement. We are thankful to Dr. N. B. Bhosle for his advice during the course of this work. We thank Dr. P. S. Parameswaran, Dr. S. S. Sawant, Mr. K. Venkat and other colleagues of MCMRD for their help. L.K. acknowledges CSIR, India, for the award of a Senior Research Fellowship. This work was supported by ONR Grant No. N 0014-940423 and is an NIO contribution (No. 3748)

\section{LITERATURE CITED}

Abu GO, Weiner RM, Rice J, Colwell RR (1991) Properties of an extracellular adhesive polymer from the marine bacterium, Shewanella colwelliana. Biofouling 3:69-84

Anil AC (1986) Studies on marine biofouling in the Zuari estuary (Goa) West coast of India. PhD thesis, Karnataka University, Dharwad

Anil AC, Khandeparker RDS (1998) Influence of bacterial exopolymers, conspecific adult extract and salinity on the cyprid metamorphosis of Balanus amphitrite (Cirripedia: Thoracica). PSZN I: Mar Ecol 19:279-292

Anil AC, Kurian J (1996) Influence of food concentration, temperature and salinity on the larval development of Balanus amphitrite. Mar Biol 127:115-124

Anil AC, Chiba K, Okamoto K, Kurokura H (1995) Influence of temperature and salinity on the larval development of Balanus amphitrite: implications in the fouling ecology. Mar Ecol Prog Ser 118:159-166

Anil AC, Khandeparker L, Mitbavker S, Wagh AB (1997) Influence of bacterial exopolymers and the adult extract of Balanus amphitrite and Cthamalus sp. on cyprid metamorphosis of Balanus amphitrite. Emerging nonmetallic materials for the marine environment. Proc US-Pacific Rim Workshop, Hawaii, Section P, p 1-11

Anil AC, Desai D, Khandeparker L (2001) Larval development and metamorphosis in Balanus amphitrite Darwin (Cirripedia: Thoracica): significance of food concentration, temperature and nucleic acids. J Exp Mar Biol Ecol 263: 125-141

Avelin Mary SR, Vitalina Mary SR, Rittschof D, Nagabhushanam R (1993) Bacterial-barnacle interaction: potential of using juncellins and antibiotics to alter structure of bacterial communities. J Chem Ecol 19:2155-2167

Bhosle NB (1981) Microbial degradation of petroleum hydrocarbons. PhD thesis, University of Bombay

Bonar DB, Weiner RM, Colwell RR (1986) Microbial-invertebrate interactions and potential for biotechnology. Microb Ecol 12:101-110

Bonar DB, Coon SL, Walch M, Weiner RM, Fitt W (1990) Control of oyster settlement and metamorphosis by endogenous and exogenous chemical cues. Bull Mar Sci 46: 484-498

Boyle CD, Reade AE (1983) Characterization of two extracel- lular polysaccharides from marine bacteria. Appl Environ Microbiol 46:392-399

Clare AS, Nott JA (1994) Scanning electron microscopy of the fourth antennular segment of Balanus amphitrite amphitrite (Crustacea:Cirripedia). J Mar Biol Assoc UK 74: 967-970

Clare AS, Rittschof D, Gerhart DJ, Maki JS (1992) Molecular approaches to nontoxic antifouling. Invertebr Reprod Dev 22:67-76

Clare AS, Freet RK, McClary MJ (1994) On the antennular secretion of the cyprid of Balanus amphitrite amphitrite, and its role as a settlement pheromone. J Mar Biol Assoc UK 74:243-250

Clare AS, Thomas RF, Rittschof D (1995) Evidence for the involvement of cyclic AMP in the pheromonal modulation of barnacle settlement. J Exp Biol 198:655-664

Crisp DJ (1974) Factors influencing the settlement of marine invertebrate larvae. In: Grant PT, Mackie AM (eds) Chemoreception in marine organisms. Academic Press, New York, p 177-265

Crisp DJ (1984) Overview of research on marine invertebrate larvae. In Costlow JD, Tipper RC (eds) Marine biodeterioration: an interdisciplinary study. Naval Institute Press, Annapolis, p 103-126

Crisp DJ (1988) Reduced discrimination of laboratory-reared cyprids of the barnacle Balanus amphitrite amphitrite Darwin, Crustacea Cirripedia, with a description of a common abnormality. In: Thompson MF, Sarojini R, Nagabhushanam R (eds) Marine biodeterioration. Balkema AA, Rotterdam, p 409-432

Crisp DJ, Meadows PS (1962) The chemical basis of gregariousness in cirripedes. Proc R Soc Lond (B) 156:500-520

Crisp DJ, Meadows PS (1963) Adsorbed layers: the stimulus to settlement in barnacles. Proc R Soc Lond (B) 158:364-387

Dagostino L, Goodman AE, Marshall KC (1990) Physiological responses induced in bacteria adhering to surfaces. Biofouling 4:113-119

Daley RJ, Hobbie JE (1975) Direct counts of aquatic bacteria by a modified epifluorescence technique. Limnol Oceanogr 20:875-882

Dalton HM, Poulsen LK, Halasz P, Angles ML, Goodman AE, Marshall KC (1994) Substratum-induced morphological changes in a marine bacterium and their relevance to biofilm structure. J Bacteriol 176:6900-6906

Davies DG, Geesey GG (1995) Regulation of the alginate biosynthesis gene algC in Pseudomonas aeruginosa during biofilm development in continuous culture. Appl Environ Microbiol 61:860-867

Davies DG, Chakrabarty AM, Geesey GG (1993) Exopolysaccharide production in biofilms: substratum activation of alginate gene expression by Pseudomonas aeruginosa. Appl Environ Microbiol 59:1181-1186

Dhople VM, Bhosle NB (1987) Dissolved carbohydrate in the central Arabian Sea. Indian J Mar Sci 16:43-45

Elyakov GB, Stonik VA, Kuznetsova TA, Mikhailov VV (1996) From chemistry of marine natural products to marine technologies. research at the Pacific Institute of bioorganic chemistry. Mar Technol Soc J 30:21-28

Fitt WK, Labare MP, Fuqua WC, Walch M, Coon SL, Bonar DB, Colwell RR, Weiner RM (1989) Factors influencing bacterial production of inducers of settlement behavior of larvae of the oyster Crassostrea gigas. Microb Ecol 17: 287-298

Fitt WK, Coon SL, Walch M, Weiner RM, Colwell RM, Bonar DB (1990) Settlement behavior and metamorphosis of oyster larvae (Crassostrea gigas) in response to bacterial supernatants. Mar Biol 106:389-394 
Gibson PH, Nott JA (1971) Concerning the fourth antennular segment of the cypris larva of Balanus balanoides. In: Crisp DJ (ed) Larval biology: light in the marine environment. Proc 4th Eur Mar Biol Symp. Cambridge University Press, Cambridge, p 227-236

Hadfield MG, Scheuer D (1985) Evidence for a soluble metamorphic inducer in Phestilla: ecological, chemical and biological data. Bull Mar Sci 37:556-566

Holmström C, Rittschof D, Kjelleberg S (1992) Inhibition of settlement of larvae of Balanus amphitrite and Ciona intestinalis by a surface-colonizing marine bacterium. Appl Environ Microbiol 58:2111-2115

Jensen R, Morse DE (1990) Chemically induced metamorphosis of polychaete larvae in both the laboratory and ocean environment. J Chem Ecol 16:911-930

Karande AA (1967) On Cirripede crustaceans (barnacles) an important fouling group in Bombay waters. Proc Symp Crustacea 1965, Ernakulum, Cochin (ser 4). Mar Biol Assoc India, p 1942-1952

Keough MJ, Raimondi PT (1995) Responses of settling invertebrate larvae to bioorganic films: effects of different types of films. J Exp Mar Biol Ecol 185:235-253

Keough MJ, Raimondi PT (1996) Responses of settling invertebrate larvae to bioorganic films: effects of large-scale variation in films. J Exp Mar Biol Ecol 207:59-68

Kirchman D, Graham S, Reish D, Mitchell R (1982a) Bacteria induce settlement and metamorphosis of Janua (Dexiospira) brasiliensis Grube (Polychaeta: Spirorbidae). J Exp Mar Biol Ecol 56:153-163

Kirchman D, Graham S, Reish D, Mitchell R (1982b) Lectins may mediate in the settlement and metamorphosis of Janua (Dexiospira) brasiliensis Grube (Polychaeta: Spirorbidae). Mar Biol Lett 3:131-142

Knight-Jones EW (1953) Laboratory experiments on gregariousness during settling in Balanus balanoides and other barnacles. J Exp Biol 30:584-598

Knight-Jones EW, Crisp DJ (1953) Gregariousness in barnacles in relation to the fouling of ships and to antifouling research. Nature 171:1109-1110

Krieg NR (ed) (1984) Bergey's manual of systematic bacteriology, Vol 1. Williams \& Wilkins, Baltimore

Kuttenreich H, Hinz HJ, Inczedy-Marcsek M, Koynova R, Tenchov B, Laggner P (1988) Polymorphism of synthetic 1,2-dialkyl-3-O-( $\beta$-D-galactosyl)-sn-glycerols of different alkyl chain lengths. Chem Phys Lipids 47:245-260

Larman VN, Gabbot PA, East J (1982) Physico-chemical properties of the settlement factor proteins from the barnacle Balanus balanoides. Comp Biochem Physiol 72B:329-338

Lau SCK, Qian PY (2001) Larval settlement in the serpulid polychaete Hydroides elegans in response to bacterial films: an investigation of the nature of putative larval settlement cue. Mar Biol 138:321-328

Lowry OH, Rosenbrough NA, Farr AL, Randall RJ (1951) Protein measurement with the Folin phenol reagent. J Biol Chem 193:265-275

Maggio B, Ariga T, Sturtevant JM, Yu RK (1985) Thermotropic behaviour of glycosphingolipids in aqueous dispersion. Biochemistry 24:1084-1092

Maki JS (1999) The influence of marine microbes on biofouling. In: Fingerman M, Nagabhushanam R, Thompson MF (eds) Recent advances in marine biotechnology. Biofilms, bioadhesion, corrosion and biofouling, Vol 3. Oxford and IBH Publishers, New Delhi, p 147-171

Maki JS, Mitchell R (1985) Involvement of lectins in the settlement and metamorphosis of marine invertebrate larvae. Bull Mar Sci 37:675-683

Maki JS, Rittschof D, Costlow JD, Mitchell R (1988) Inhibition of attachment of larval barnacles, Balanus amphitrite, by bacterial surface films. Mar Biol 97:199-206

Maki JS, Rittschof D, Schmidt AR, Snyder AG, Mitchell R (1989) Factors controlling attachment of bryozoan larvae: a comparison of bacterial films and unfilmed surfaces. Biol Bull 177:295-302

Maki JS, Rittschof D, Samuelsson MO, Szewzyk U, Kjelleberg S, Costlow JD, Mitchell R (1990) Effect of marine bacteria and their exopolymers on the attachment of barnacle cypris larvae. Bull Mar Sci 46:499-511

Maki JS, Rittschof D, Mitchell R (1992) Inhibition of larval barnacle attachment to bacterial films: an investigation of physical properties. Microb Ecol 23:97-106

Maki JS, Yule AB, Rittschof D, Mitchell R (1994) The effect of bacterial films on the temporary adhesion and permanent fixation of cypris larvae, Balanus amphitrite Darwin. Biofouling 8:121-131

Morse ANC (1991a) How do planktonic larvae know where to settle? In some species the key is a chemical cue which induces settling through biochemical pathways similar to those operating in the human nervous system. Am Sci 79: 154-167

Morse ANC (1991b) GABA-mimetic peptides from marine algae and cyanobacteria as potential diagnostic and therapeutic agents. In: Thompson $\mathrm{MF}$, Sarojini R, Nagabhushanam R (eds) Bioactive compounds from marine organisms. Oxford and IBH Publishers, New Delhi, p $167-172$

Morse DE (1984a) Biochemical control of larval recruitment and marine fouling. In: Costlow JD, Tipper RC (eds) Marine biodeterioration: an interdisciplinary study. Naval Institute Press, Annapolis, p 134-140

Morse DE (1984b) Biochemical and genetic engineering for improved production of abalones and other valuable molluscs. Aquaculture 39:263-282

Morse DE (1985) Neurotransmitter-mimetic inducers of settlement and metamorphosis of marine planktonic larvae. Bull Mar Sci 37:697-706

Morse DE (1990) Recent progress in larval settlement and metamorphosis: closing the gaps between molecular biology and ecology. Bull Mar Sci 46:465-483

Morse DE, Tegner M, Duncan H, Hooker N, Trevelyan G, Cameron A (1980) Induction of settling and metamorphosis of planktonic molluscan (Haliotis) larvae. III. Signaling by metabolites of intact algae is dependent on contact. In: Muller Schwarze D, Silverstein RM (eds) Chemical signals. Plenum Press, New York, p 67-86

Müller WA (1973) Induction of metamorphosis by bacteria and ions in the planulae of Hydractinia echinata: an approach to the mode of action. In: Tokidka T, Nishimura $\mathrm{S}$ (eds) Proc 2nd Int Symp Cnidaria, Kyoto University. Publ Seto Mar Biol Lab Spec Publ Ser 20:195-208

Musch A (1996) Dose-time-effect relationships. In: Niesink RJM, John de Vries, Hollinger MA (eds) Toxicology. Principles and applications. CRC Press, Boca Raton, FL, p 187-237

Neal AL, Yule AB (1992) The link between cypris temporary adhesion and settlement of Balanus balanoides (L.). Biofouling 6:33-38

Neal AL, Yule AB (1994a) The tenacity of Elminius modestus and Balanus perforatus cyprids to bacterial films grown under different shear regimes. J Mar Biol Assoc UK 74: 251-257

Neal AL, Yule AB (1994b) The interaction between Elminius modestus Darwin cyprids and biofilms of Deleya marina NCMB 1877. J Exp Mar Biol Ecol 176:127-139

Neumann R (1979) Bacterial induction of settlement and 
metamorphosis in the planula larvae of Cassiopea andromeda (Cnidaria:Scyphozoa, Rihzostomeae). Mar Ecol Prog Ser 1:21-28

O'Connor NJ, Richardson DL (1996) Effects of bacterial films on attachment of barnacle (Balanus improvisus Darwin) larvae: laboratory and field studies. J Exp Mar Biol Ecol 206:69-81

O'Connor NJ, Richardson DL (1998) Attachment of barnacle (Balanus amphitrite Darwin) larvae: responses to bacterial films and extracellular materials. J Exp Mar Biol Ecol 226: 115-129

Pawlik JR (1990) Natural and artificial induction of metamorphosis of Phramatopoma lapidosa californica (Polychaeta: Sabellariidae), with a critical look at the effects of bioactive compounds on marine invertebrate larvae. Bull Mar Sci 46:512-536

Pawlik JR (1992) Chemical ecology of the settlement of benthic marine invertebrates. Oceanogr Mar Biol Annu Rev 30:273-335

Pechenik JA (1990) Delayed metamorphosis by larvae of benthic marine invertebrates: Does it occur? Is there a price to pay? Ophelia 32:63-94

Perkins FO (1973) A new species of marine labyrinthulid Labyrinthuloides yorkensis gen. nov. spec. nov.: cytology and fine structure. Arch Mikrobiol 90:1-17

Pielou EC (1984) The interpretation of ecological data. John Wiley \& Sons, New York, p 263

Qian PY, Rittschof D, Sreedhar B (2000) Macrofouling in unidirectional flow: miniature pipes as experimentals for studying the interaction of flow and surface characteristics on attachment of barnacle, bryozoan and polychaete larvae. Mar Ecol Prog Ser 207:109-121

Raghukumar S, Anil AC, Khandeparker L, Patil JS (2000) Thraustochytrid protists as a component of marine microbial films. Mar Biol 136:603-609

Rittschof D (1985) Oyster drills and the frontiers of chemical ecology: unsettling ideas. Am Malacol Bull Spec Edn 1: 111-116

Rittschof D, Branscomb ES, Costlow JD (1984) Settlement and behavior in relation to flow and surface in larval barnacles, Balanus amphitrite Darwin. J Exp Mar Biol Ecol 82: 131-146

Rodriguez SR, Ojeda FP, Inestrosa NC (1993) Settlement of benthic marine invertebrates. Mar Ecol Prog Ser 97: 193-207

Satuito CG, Shimizu K, Fusetani N (1997) Studies on the

Editorial responsibility: John Dolan,

Villefranche-sur-Mer, France factors influencing larval settlement in Balanus amphitrite and Mytilus galloprovincialis. Hydrobiologia 358: 275-280

Schmahl G (1985) Bacterially induced stolon settlement in the scyphopolyp of Aurelia aurita (Cnidaria, Scyphozoa). Helgol Meeresunters 39:33-42

Sokal RR, Rohlf FJ (1981) Biometry, 2nd edn. WH Freeman \& Company, San Francisco

Strathmann RR, Branscomb ES, Vedder K (1981) Fatal errors in set as a cost of dispersal and the influence of intertidal flora on set of barnacles. Oecologia 48:13-18

Szewzyk U, Holmström C, Wrangstadh M, Samuelsson MO, Maki JS, Kjelleberg S (1991) Relevance of the exopolysaccharide of marine Pseudomonas sp. strain S9 for the attachment of Ciona intestinalis larvae. Mar Ecol Prog Ser 75:259-265

Tamburri MN, Zimmer-Faust RK, Tamplin ML (1992) Natural sources and properties of chemical inducers mediating settlement of oyster larvae: a re-examination. Biol Bull Mar Biol Lab Woods Hole 183:327-338

Unabia CRC, Hadfield MG (1999) Role of bacteria in larval settlement and metamorphosis of the polychaete Hydroides elegans. Mar Biol 133:55-64

Walker G, Yule AB (1984) Temporary adhesion of the barnacle cyprid: the existence of an antennular adhesive secretion. J Mar Biol Assoc UK 64:679-686

Wieczorek SK, Clare AS, Todd CD (1995) Inhibitory and facilitory effects of microbial films on settlement of Balanus amphitrite amphitrite larvae. Mar Ecol Prog Ser 119: 221-228

Yamamoto HA, Tachibana A, Matsumura K, Fusetani N (1995) Protein kinase C (PKC) signal transduction system involved in larval metamorphosis of the barnacle, Balanus amphitrite. Zool Sci 12:391-396

Yamamoto Y, Tachibana A, Kawaii S, Matsumura K, Fusetani $N$ (1996) Serotonin involvement in larval settlement of the barnacle, Balanus amphitrite. J Exp Zool 275:339-345

Yule AB, Crisp DJ (1983) Adhesion of cypris larvae of the barnacle Balanus balanoides, to clean and arthropodin treated surfaces. J Mar Biol Assoc UK 63:261-271

Yule AB, Walker G (1985) Settlement of Balanus balanoides: the effect of cyprid antennular secretion. J Mar Biol Assoc UK 65:707-712

Zimmer-Faust RK, Tamburri MN (1994) Chemical identity and ecological implications of a waterborne, larval settlement cue. Limnol Oceanogr 39:1075-1087

Submitted: November 8, 2001; Accepted: March 12, 2002

Proofs received from author(s): April 23, 2002 